\title{
Структурные и петрографические особенности ультрамафитов на участке «месторождение №33» в восточной части массива Средний Крака (Южный Урал)
}

\author{
Д.Е. Савельев ${ }^{a}$, Д.А. Кожевников

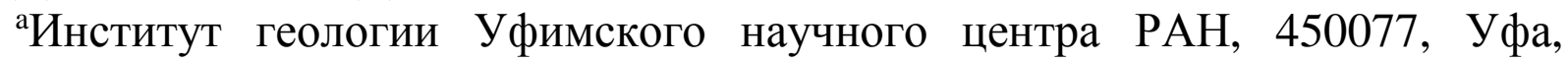 \\ ул. К.Маркса, 16/2. E-mail: sav171@ mail.ru \\ ${ }^{\mathrm{b}}$ Объединенный институт ядерных исследований, 141980, Дубна, Москов- \\ ская обл., ул. Жолио-Кюри, 6. E-mail: dkozhevn@jinr.ru \\ (Статья поступила в редакиию 20 января 2015 г.)
}

\begin{abstract}
Приведены результаты структурного изучения хромитоносных ультрамафитов с использованием методов петрографии и рентгеновской томографии. Показано, что образование рудных концентраций хромита обусловлено твердофазным (реоморфическим) перераспределением мантийного вещества при вязкопластическом течении. На примере тонких прожилков в перидотитах исследованы структуры, возникающие на начальной стадии образования дунита. Показано, что новые зерна хромшпинелидов в дуните образовались при деформационно-индуцированной сегрегации хрома из зерен оливина. Сначала возникли ультрамелкие частицы хромшпинелидов и их нитевидные сегрегации вдоль границ деформированного оливина, затем происходили коалесценция и сфероидизация этих выделений. Проводится аналогия наблюдаемых структур с образующимися при пластической деформации металлов и сплавов.
\end{abstract}

Ключевые слова: ультрамафиты, хромититы, пластическая деформация, петроструктура оливина, сегрегация, коалесиенция, реоморфизм, Южный Урал, Крака.

DOI: $10.17072 /$ psu.geol.26.60

\section{Постановка проблемы}

Ультрамафитовые массивы, обнажающиеся в складчатых поясах и входящие в состав офиолитовых комплексов, принято отождествлять с фрагментами верхней мантии геологического прошлого. Наряду с геофизическими данными и изучением ксенолитов ультраосновного состава, доставленных из мантии базальтовыми расплавами, исследование рассматриваемых комплексов пород позволяет получить

(С) Савельев Д.Е., Кожевников Д.А., 2015 важную информацию о строении и составе глубинных геосфер нашей планеты.

На протяжении долгого времени ультраосновные породы офиолитовых комплексов рассматривались как дифференциаты магматического расплава $[12,14$, $34 ; 19,53]$, при обсуждении механизмов их образования обычно проводились параллели с расслоенными интрузиями платформенного типа. Резкие структурные и вещественные отличия между ними объяснялись лишь спецификой геодинамических условий становления $[18,45$, 
53]. Однако некоторые важные особенности строения офиолитовых ультрамафитов, в частности большая мобильность наиболее тугоплавкой дунитовой минеральной ассоциации (оливин+хромит) по сравнению с перидотитами, привели к кризису магматической гипотезы. По этой причине появились альтернативные модели - метасоматическая [3, 6, 16, 17, 21], латераль-секреционная [35, 36], реакционно-магматическая [4, 48, 54], а также различные комбинированные варианты магматической гипотезы, включая механизмы смешения магм [41, 49 - 51].

Bce упомянутые выше гипотезы объединяет взгляд на мантийные ультрамафиты как преимущественно пассивную субстанцию, которая преобразуется главным образом геохимически при проработке ее расплавами и/или флюидами. Вместе с тем многочисленными структурнопетрологическими исследованиями показано, что мантийные ультрамафиты представляют собой типичные высокотемпературные тектониты, современный облик которых предопределен интенсивной пластической деформацией $[10,38,39,42$, 52]. А поскольку сегодня считается общепринятым наличие в мантии потоков кристаллического вещества, можно предполагать, что наблюдаемые структурновещественные особенности ультрамафитов были сформированы при их вязкопластическом подъеме внутри одного из таких потоков. Данный подход к решению проблемы происхождения офиолитовых ультрамафитов развивается в работах одного из авторов настоящей статьи [22 31] и некоторых других отечественных исследователей $[1,2,7,33,38]$.

Изучению офиолитовых ультрамафитов в настоящее время уделяется много внимания во всем мире, но, несмотря на это, многие из вопросов, касающихся механизмов формирования их внутренней структуры и состава, остаются нерешенными. Настоящее исследование посвящено одному из аспектов обозначенной проблемы - происхождению хромитовой минерализации в дунитовых телах среди пе- ридотитов на начальной стадии их образования.

\section{Объект и методика исследований}

Для проведения детальных структурных и петрографических исследований нами был выбран участок, непосредственно прилегающий к рудному телу месторождения №33 (упоминавшегося также под названием «Шарыпкинская разведка» [34]) на массиве Средний Крака (рис.1).

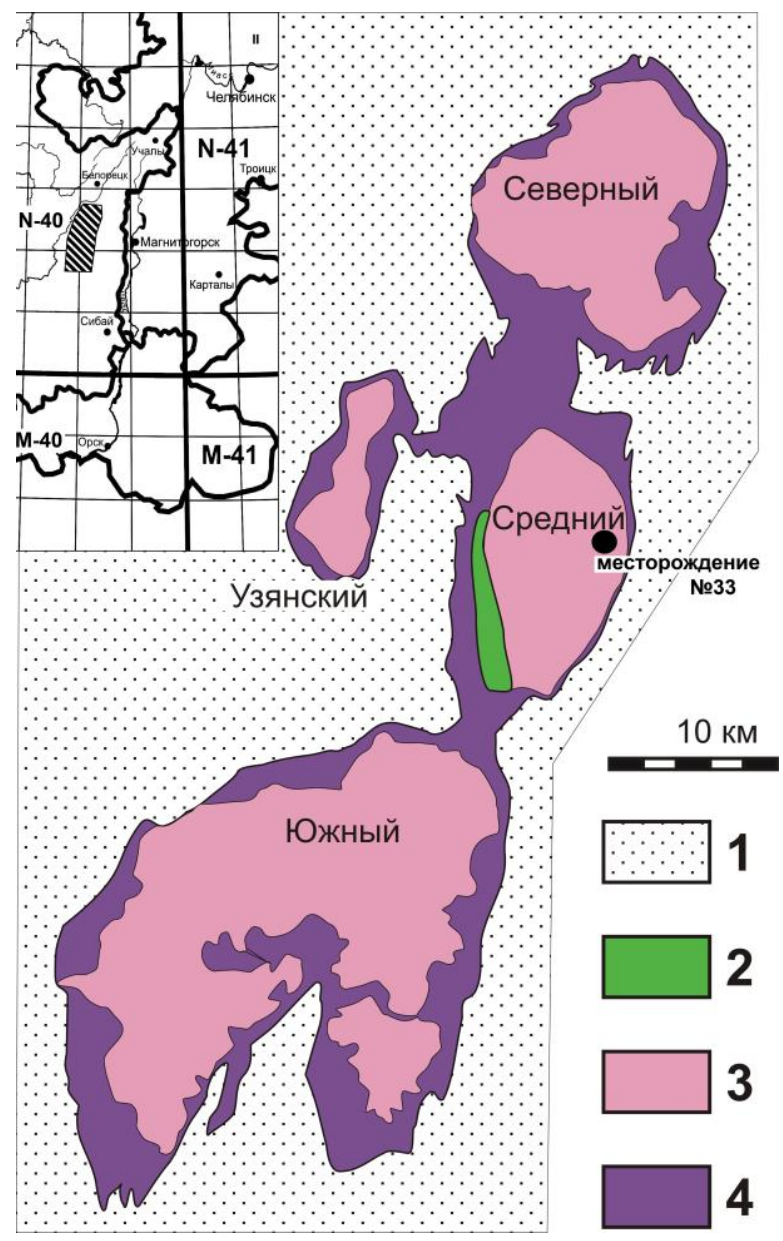

Рис.1. Обзорная геологическая схема массивов Крака: 1 - вмещающие осадочные и вулканогенно-осадочные породы Зилаирского мегасинклинория, 2 - габбро, верлиты и клинопироксениты («габброидный комплекс»), 3 шпинелевые перидотиты $c$ подчиненными дунитовыми телами («реститовыгй ультрабазитовый комплекс»), 4 - серпентиниты тектонизированные («меланж») 

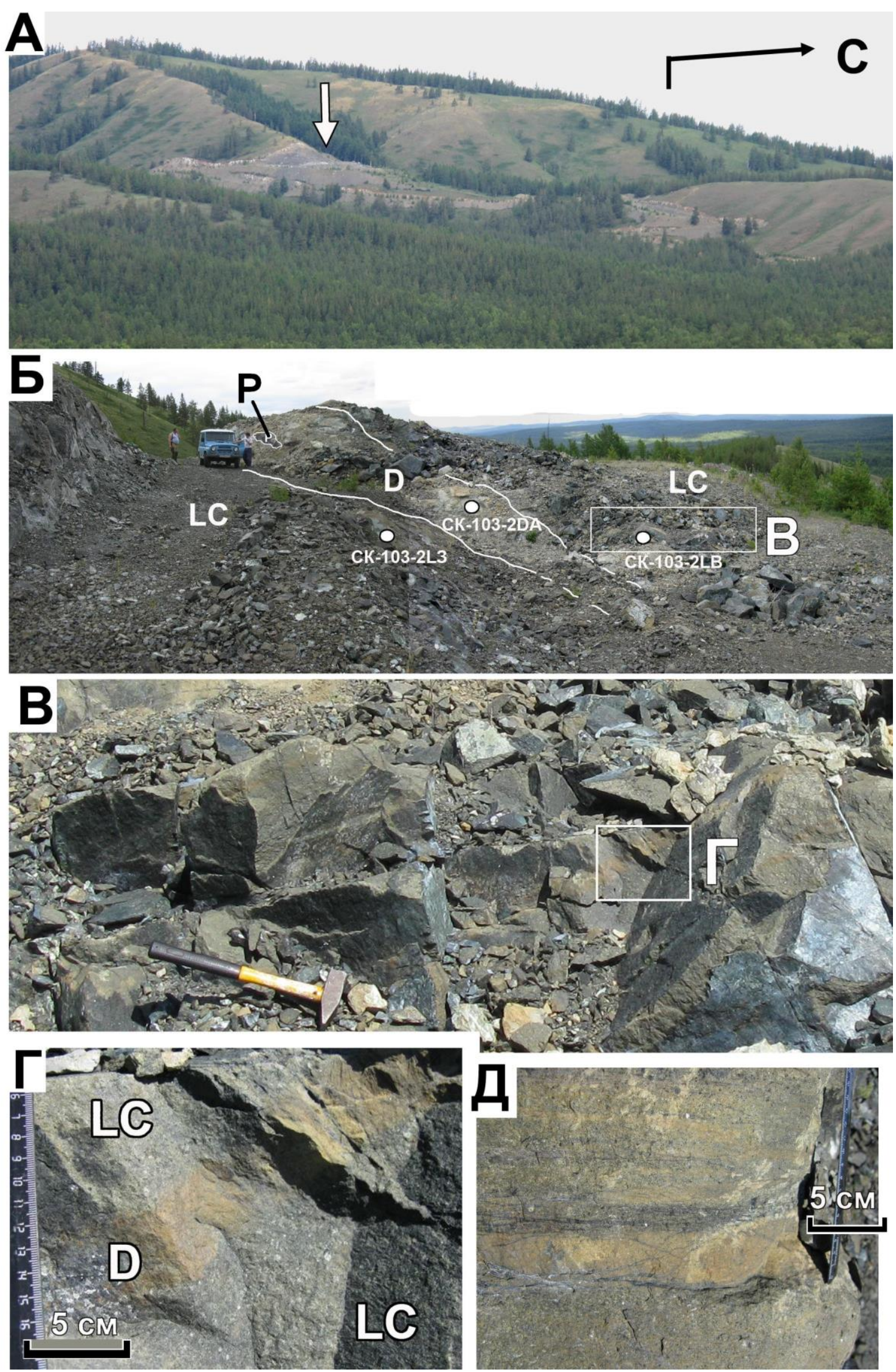

Рис.2. Общий вид участка и макроскопические детали геологического строения: $A$ - вид на месторождение от д. Шарипово; Б- общий вид участка с запада; B - точка CK-103-2LB, в 2 м восточнее контакта рудовмещзающих дунитов с перидотитами; $\Gamma$, Д-дунитовые прожсилки в перидотитах; LC-nеридотить, $D$ - дунить, $P$-хромитить 
Данное месторождение расположено в восточной части массива, в 1,5 км западнее тектонического контакта ультрамафитов с вмещающими осадочными породами восточного крыла Зилаирского мегасинклинория.

Выбор объекта исследований обусловлен: 1) хорошей обнаженностью территории, вскрытой при опытно-технологическом опробовании хромититов (рис.2); 2) небольшими размерами месторождения, позволяющими на коротком расстоянии наблюдать переходы от перидотитов к рудовмещающим дунитам и хромовым рудам; 3) развитием на данном участке, наряду с рудовмещающим дунитовым телом, многочисленных прожилков в перидотитах, которые фиксируют начальные стадии процесса образования дунитов; 4) присутствием на месторождении нодулярных хромовых руд, генезис которых часто a priori рассматривается как магматический [18].

Полевые геологические исследования на объекте включали в себя картирование участка месторождения, составление погоризонтных планов и разрезов в ходе его опытно-промышленной эксплуатации, отбор ориентированных образцов для петроструктурного изучения. Из ориентированных образцов шпинелевых перидотитов и дунитов изготавливались полированные шлифы в трех взаимно перпендикулярных плоскостях. Результаты петроструктурных исследований ультрамафитов и генезис нодулярных хромититов обсуждены в нескольких предыдущих публикациях одного из авторов [23 - 25] и поэтому здесь подробно не рассмотрены. Главное внимание в данном исследовании было уделено изучению распределения зерен породообразующих минералов в пространстве и возможным механизмам: 1) обособления мономинерального дунитового слоя, 2) образования и концентрирования в этом слое зерен хромшпинелидов.

Для изучения 3D-структуры дунитового прожилка были применены методы рентгеновской томографии. Сканирование проводилось на микротомографе MARS, произведенном в Новой Зеландии и установленном в Лаборатории ядерных проблем Объединенного института ядерных исследований (г. Дубна, Московская обл.). В данном томографе образец не вращается, располагается горизонтально и может перемещаться вдоль горизонтальной оси вращения штативно-поворотного устройства с источником рентгеновского излучения и камерой, используется геометрия с конусным пучком. Томограф предназначен для сканирования объектов длиной не более 30 см и диаметром не более $10 \mathrm{~cm}$. В качестве источника рентгеновского излучения использовалась трубка SB-120 при пиковом напряжении 120 кВ и токе 350 мкА.

Для уменьшения эффекта ужесточения пучка использовался алюминиевый фильтр толщиной 2 см, поглощающий мягкую часть спектра излучения. Камера, детектирующая рентгеновское излучение, состоит из двух гибридных пиксельных детекторов на основе электроники Medipix3 и сенсора из GaAs:Cr. Каждый детектор имеет квадратную форму 14,1 х 14,1 мм; 256 х 256 пикселей, размером 55 х 55 мкм. Расстояние от источника излучения до оси вращения 129 мм, расстояние от источника излучения до камеры 222,4 мм, что обеспечило геометрическое увеличение в 1,72 раза. При этом линейный размер вокселя реконструируемого изображения составил приблизительно 32 мкм, а предельное разрешение томографа около 50 мкм. Реконструкция проводилась с помощью программного обеспечения Octopus, a 3D-визуализация - с помощью программы Voreen 4.4.

Для изучения особенностей внутреннего строения рудовмещающих пород был проведен количественный петрографический анализ (image analysis), включающий определение гранулометрического состава пород и ориентировки зерен и других элементов структуры на статистической основе. Специфика ультрамафитов заключается в том, что простого 

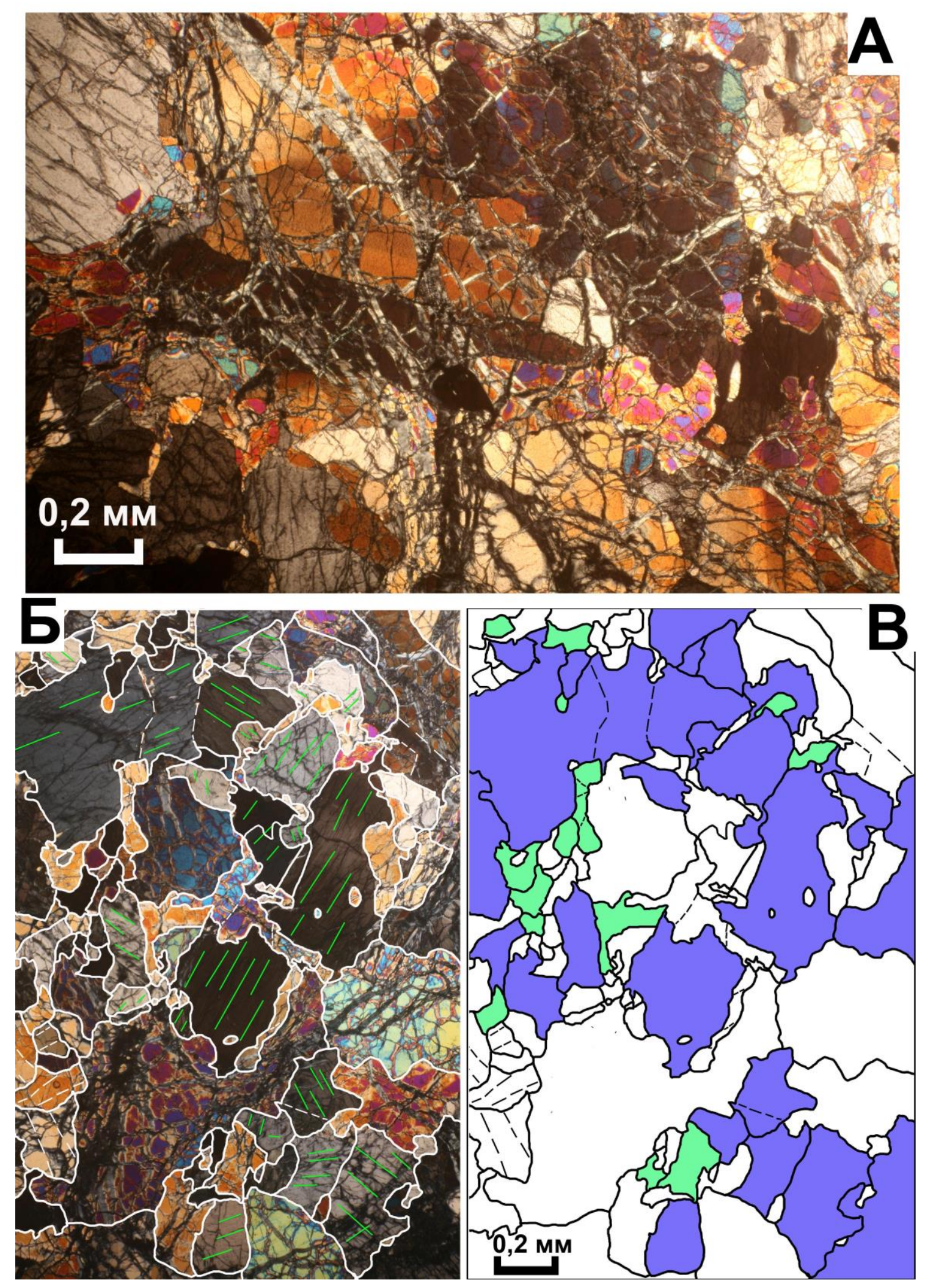

Рис. 3. Деформационная микроструктура в образие перидотита (А) и результаты обработки изображения микроструктуры для проведения количественных петрографических исследований - «имидж-анализа» (Б, В). Шлиф СК-103-2LB2. Условные обозначения к рис. 3В см. на рис. 5, 6; пунктиром показаны малоугловые границы (границы субзерен, полосы скольжения) 
фотографирования в проходящем свете и в скрещенных николях недостаточно для создания петрографических карт, пригодных для обсчета в соответствующих программах. Поэтому сначала составлялись фотопанорамы в проходящем свете, а затем на эту основу наносились границы зерен, как показано на рис. 3. Расположение зерен хромшпинелидов выполнялось в качестве накладки со сканированного изображения шлифа. Готовые петрографические карты обрабатывались в программе Image Tool, имеющейся в свободном доступе в сети Интернет. Результаты расчетов позволили на статистической основе определить интенсивность ориентировки зерен различных минералов, плоскости минеральной уплощенности и линейность, а также гранулометрический состав пород и содержание отдельных минералов.

Петроструктурные исследования проводились по известной методике, подробные описания которой содержатся в ряде работ $[11,32]$. Первичные данные ориентировок оптических индикатрис оливина наносились на проекцию верхней полусферы равноплощадной сетки Шмидта. Исследования проводились в шлифах, из- готовленных в различных плоскостях, поэтому для их более удобного сравнения между собой и с экспериментальными данными был произведен поворот диаграмм по методике, описанной в ряде руководств [11, 15]. Залегание плоскостей минеральной уплощенности и линейности определялось по данным измерения линейных элементов структуры в трех взаимно перпендикулярных срезах по методике А.И. Чернышова [37].

\section{Фактический материал}

Описание месторождения содержится в серии работ [ 23 - 25, 28, 31, 34], поэтому ниже приведена лишь краткая геологогеохимическая характеристика пород. В разрезе рудоносной зоны преимущественным распространением пользуются шпинелевые перидотиты, имеющие следующий состав: оливин $>65 \%$, ортопироксен 15-30\%, клинопироксен 2-7\%, шпинелиды 0,n - 1\%. Дуниты встречаются только в непосредственной близости от хромититов, образуя вокруг них оторочку мощностью от 0,5 до 3 м и тонкие прожилки в перидотитах на восточном фланге рудоносной зоны (рис.2, 4).

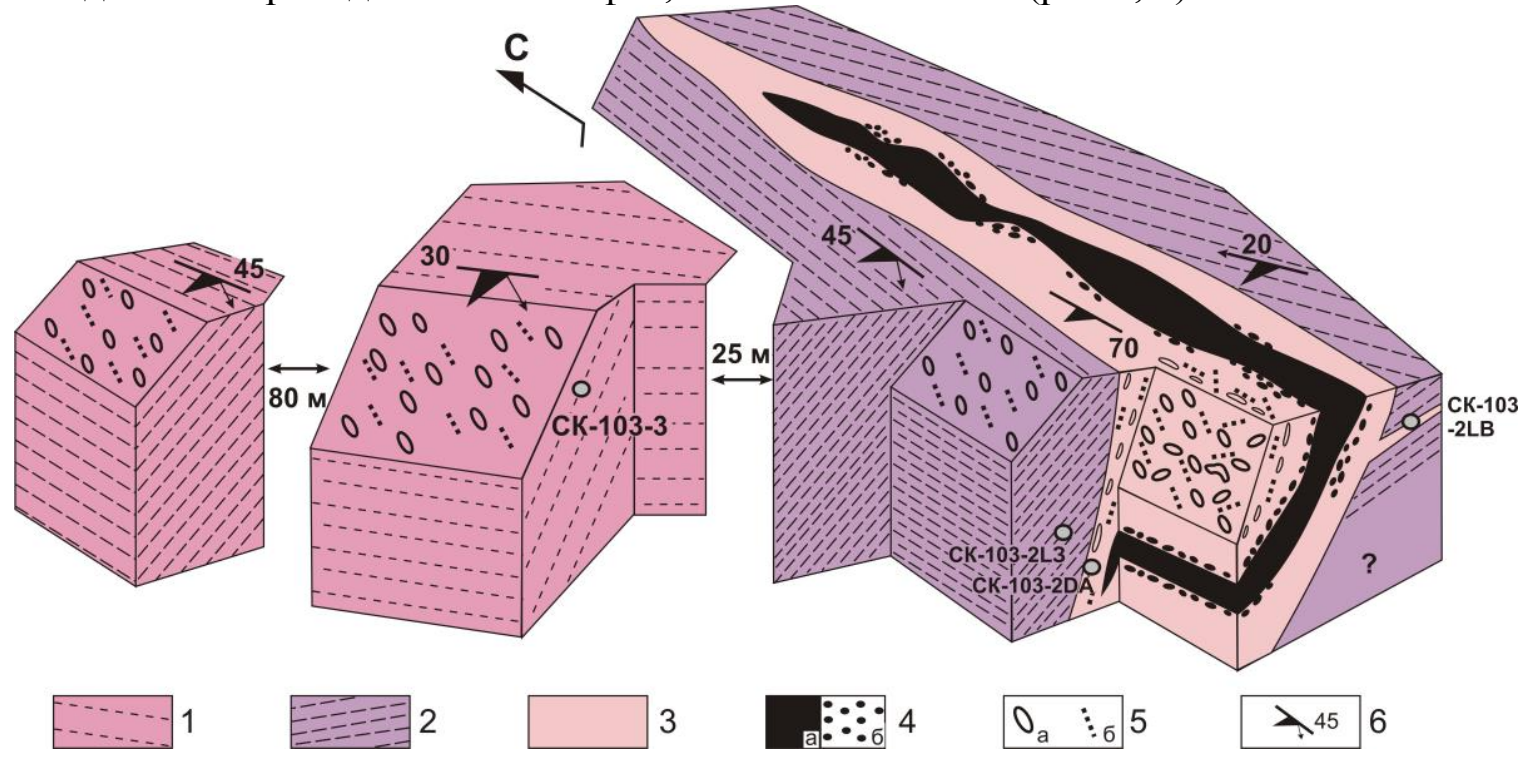

Рис.4. Геологическое строение участка месторождения №33 по данным [23 - 25]: 1 - 2 шпинелевые перидотиты с различным содержанием ортопироксена $(1-<20 \%, 2$ - >20\%), 3 дуниты, 4 - хромититы массивные (а) и нодулярные (б), 5 - ориентировка зерен оливина (а) и агрегатов хромшпинелидов (б) на плоскостях минеральной сланцеватости, 6 - залегание структурных элементов (минеральной уплощенности и линейности) в ультрамафитах 
Породы габброидного состава, часто отмечающиеся в пределах хромитоносных зон офиолитов и считающиеся продуктами кристаллизации дифференциатов базальтоидной выплавки [31], на изученной площади не встречены.

В ультрамафитах установлены следующие минералого-геохимические закономерности [28]. В перидотитах с приближением к рудному телу происходит увеличение содержания пироксенов от 17-20 до 25-30\%, которое резко падает до нуля в околорудных дунитах. В перидотитах на удалении от рудоносной зоны акцессорный шпинелид низкохромистый (20,59$43,05 \%$ Cr2O3) и высокоглиноземистый (26,77-45,55\% A12О3). По мере приближения к рудному телу в шпинелидах перидотитов постепенно увеличивается глиноземистость вплоть до точки CK-103-2L3 с наиболее высоким содержанием Al2O3 $(52,34-54,87 \%$ \%) и низкой концентрацией хрома $(12,56-15,3 \%$ Cr2O3). В дунитах шпинелид высокохромистый $\quad(53,94-$ $55,13 \%$ Cr2O3), максимальные содержания хрома отмечены в массивных крупнозернистых и нодулярных хромититах (60,8-62,2\% Cr2O3). В перидотитах, примыкающих к дунитам с востока, содержание хрома в шпинелиде вновь снижается $(21,73-35,89 \%$ Cr2O3).

Закономерное изменение состава хромшпинелидов, наблюдаемое в масштабе участка (первые метры - десятки метров), сохраняется и в масштабе штуфов (миллиметры - сантиметры). Наиболее интересные данные была получены по образцу CK-103-2LB, отобранному в 2 м восточнее контакта околорудных дунитов со шпинелевыми перидотитами. В перидотитах отмечаются дунитовые полосы мощностью 1-5 см, одна из которых и представлена в упомянутом образце. Изучение образца СК-103-2LB показало, что содержание хрома в шпинелидах возрастает от лерцолитового края шлифа к центру дунитового прожилка от 21,73 до $35,89 \%$. Одновременно концентрация $\mathrm{Cr} 2 \mathrm{O} 3$ уменьшается в оливине от 0,2 до $<0,01 \%$.
Переходя к описанию петрографических особенностей пород, прежде всего следует отметить, что, несмотря на довольно значительную степень серпентинизации изученных образцов ультрамафитов (от 30 до 60\%), во всех случаях она носит квазистатический характер, о чем говорит отсутствие смещений первичных высокотемпературных полос скольжения в оливине прожилками петельчатого серпентина (рис.3). Во всех изученных образцах диагностированы деформационные структуры, образованные на этапе высокотемпературного пластического течения в верхней мантии. Породы претерпели проникающие пластические деформации, которые выразились как в образовании преимущественной ориентировки зерен оливина по форме, так и в формировании отчетливых петроструктурных узоров [23-25]. Минеральная уплощенность зерен оливина подчеркивается ориентировкой агрегатов хромшпинелидов, хотя макроскопическая полосчатость, характерная для дунит-гарцбургитового комплекса, на изученном участке почти не проявлена.

Рудовмещающие дуниты (обр. СК103-2DA) характеризуются разнозернистым строением, структуру можно определить как порфиробластовую (рис.5). В породе примерно одинаковый объем приходится на крупные зерна - порфиробласты (более 2 мм) и мелкие вытянутые либо изометричные зерна (0,4-1,2 мм). В количественном же отношении резко преобладают мелкие зерна, а максимум встречаемости приходится на зерна с величиной среднего сечения 0,5-0,9 мм. В большинстве зерен оливина отмечаются следы пластических деформаций, которые выражены в образовании полос излома в оливине и пироксенах, неоднородном погасании зерен, обусловленном разориентацией блоков зерен на небольшой угол. Деформированность в разных зернах выражена с различной интенсивностью. Наряду с порфиробластами, состоящими из блоков, погасающих в скрещенных николях «клавишеобразно» и разделенных четкими полосами излома, встречаются 
крупные зерна практически без признаков блокования. По-видимому, рост крупных зерен оливина без видимых признаков деформации происходит по механизму посттектонической рекристаллизации в «тенях давления» за счет наиболее искаженных соседних участков.

Содержание в околорудном дуните хромшпинелидов сильно варьирует от участка к участку. В большей части объема породы оно составляет $0,5-1,5 \%$, но иногда может достигать 4-8\%. Одновременно с увеличением концентрации хромшпинелидов растет размер их зерен. Размер зерен изменяется от 0,05 до 1,0 мм, при этом они чаще имеют удлиненную форму, также характерно формирование агрегатов, вытянутых в одном направлении. При увеличении размера зерна хромшпинелидов становятся более изометричными.

Геометрическая ориентировка зерен оливина в горизонтальной (А) и вертикальной широтной $(\mathrm{C})$ плоскостях весьма совершенна и позволяет идентифицировать плоскость уплощенности, имеющую следующую ориентировку: аз. пад. $240^{\circ}$, $\angle 75^{\circ}$. Ближайшей плоскостью к плоскости минерального уплощения является вертикальная меридиональная плоскость (B), в ней залегает линейность, которая в исследуемом образце выражена нечетко. По данным статистического расчета получено несколько максимумов удлинения зерен оливина, из которых наиболее интенсивны следующие: 1) субгоризонтальный - аз. склонения $\left.150^{\circ}, \angle 5^{\circ}, 2\right)$ наклонный - аз. склонения $160^{\circ}, \angle 50^{\circ}$. Ориентировка зерен и агрегатов хромшпинелидов во всех трех плоскостях характеризуется наличием двух максимумов. Наиболее интенсивные максимумы в горизонтальной и вертикальной широтной плоскостях соответствуют таковым, выявленным по оливину, а в вертикальной меридиональной плоскости наиболее интенсивный максимум совпадает со вторым по значению максимумом оливина. Таким образом, по комплексу данных ориентировки зерен и агрегатов оливина и хромшпинелида определяем положение главной плоскости минеральной уплощенности (аз. пад. $240^{\circ}$, $\angle 75^{\circ}$ ) и направление линейности (аз. склонения $160^{\circ}, \angle 50^{\circ}$ ). Вторая по значению система, фиксируемая по ориентировке хромшпинелидов, имеет субгоризонтальное залегание с линейностью, погружающейся на СB 55

В 1 м западнее контакта дунитов, обрамляющих хромититовое тело, был взят образец CK-103-2L3, представленный шпинелевым перидотитом, состоящим из оливина (73\%), ортопироксена (23\%), клинопироксена $(2,5 \%)$ и хромшпинелида $(1,5 \%)$. Порода обладает разнозернистой (порфиробластовой) структурой. Оливин образует крупные деформированные удлиненные зерна размером более 1,5 мм, для которых характерно взаимно параллельное расположение. Примерно одинаковые объемы в образце заняты крупными порфиробластами и мелкими зернами оливина. Последние чаще имеют изометричную, реже - удлиненную форму. По данным статистических расчетов наиболее распространенным средним размером среза является 0,3-0,6 мм.

Ортопироксен представлен также двумя типами зерен: 1) крупными порфиробластами (более 1,2 мм) и 2) мелкими необластами (0,2-0,7 мм). Для крупных зерен наиболее характерны изометричные очертания и отчетливые следы хрупкопластической деформации, которая отражена в неоднородном погасании, изгибе плоскостей спайности, образовании кинкбандов. Во многих зернах отмечается переход энстатита в клиноэнстатит, что обычно связывается с деформационным процессом [39, 42 и др.]. Хрупкая деформация энстатита отражена в таком явлении, как разрушение крупных зерен (>2 мм) с образованием на их месте скоплений крупных и мелких зерен, а также внедряющегося вдоль ослабленных направлений мелкозернистого оливина. 


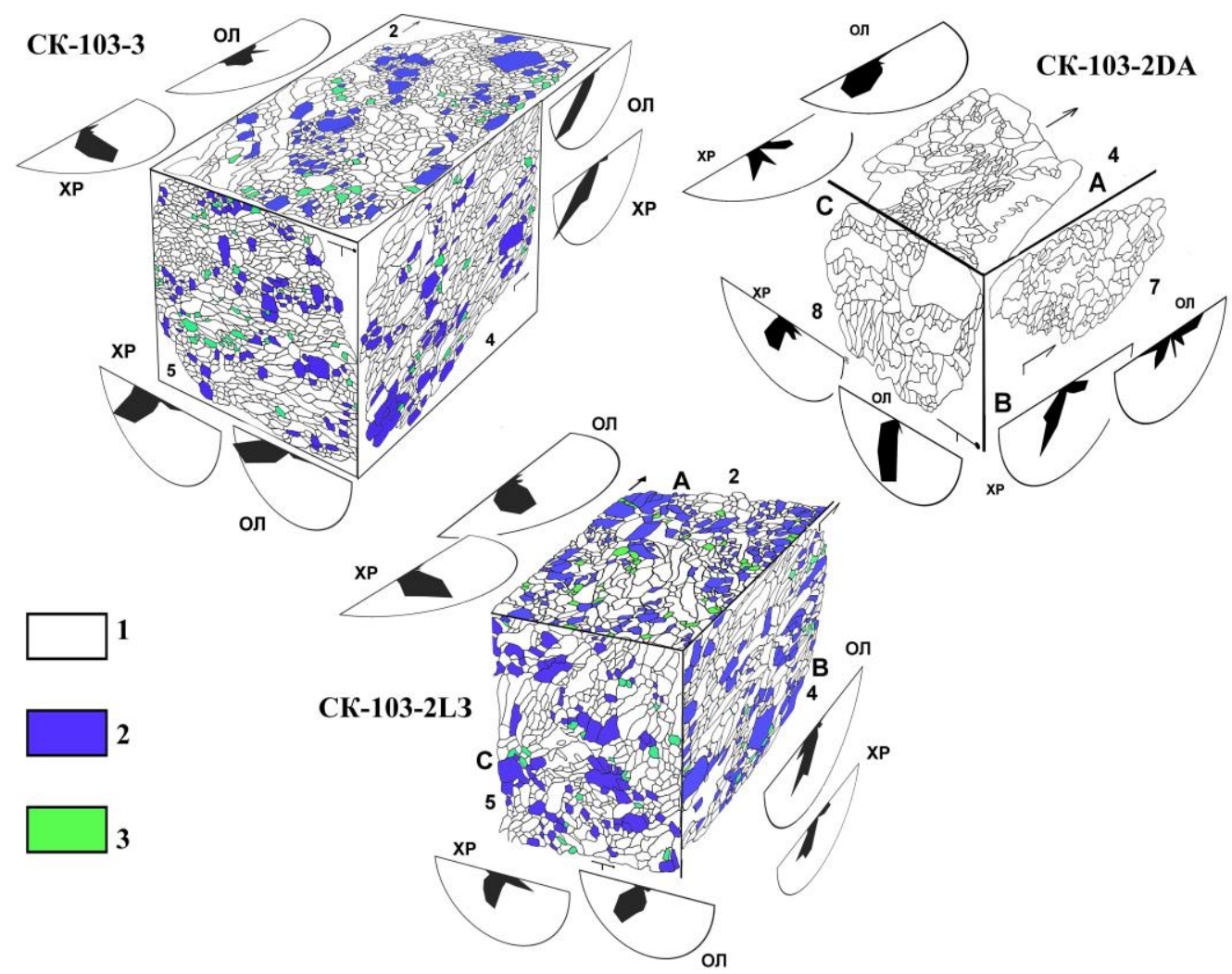

Рис.5. Блок-диаграммы образиов перидотитов и дунитов участка «месторождение №33» и розы диаграммы ориентировки удлиненных зерен оливина и хромшпинелида: 1 - оливин, 2 - ортопироксен, 3 - клинопироксен; сокращения: ол-оливин, хр - хромшпинелид. Цифры на плоскостях блок-диаграмм обозначают номера шлифов, которые использованы при составлении изображений (например: СК-103-3-2 - для горизонтальной плоскости образиа СК-103-3)

Клинопироксен в рассматриваемом образце присутствует в виде мелких зерен таблитчатой формы размером 0,15 - 0,6 мм, они имеют тенденцию группироваться в определенных участках шлифа и обычно тяготеют к сегрегациям ортопироксена. Хромшпинелид образует мелкие, часто вытянутые зерна размером 0,05-0,2 мм. Агрегаты хромшпинелидов постоянно ассоциируют с пироксенами, особенно с диопсидом.

По данным изучения шлифов, сделанных в трех взаимно перпендикулярных плоскостях, в рассматриваемом образце выявляется четкая минеральная уплощенность зерен оливина в горизонтальном и вертикальном широтном срезах (аз. пад. $\left.225^{\circ}, \angle 60^{\circ}\right)$. Линейность, идентифицируемая в вертикальной меридиональной плоскости, погружается на юг (аз. склонения $\left.190^{\circ}, \angle 50^{\circ}\right)$. Таким образом, ориентировка оливина в шпинелевых перидотитах, непосредственно примыкающих к ру- довмещающему дунитовому телу, практически совпадает с таковой в дунитах.

Ориентировка агрегатов хромшпинелидов в образце CK-103-2L3 близка к таковой оливина, но обладает некоторой спецификой: 1) в горизонтальной плоскости между максимумами удлинения оливина и хромшпинелида угол составляет около $\left.15^{\circ} ; 2\right)$ в широтном вертикальном срезе наряду с главным максимумом, соответствующим таковому оливина, в хромшпинелидах проявлен и второй небольшой по интенсивности максимум с пологим восточным погружением. Линейность идентифицируется в вертикальной меридиональной плоскости по совпадающим максимумам удлинения оливина и хромшпинелида, что соответствует аз. склонения $190^{\circ}, \angle 50^{\circ}$.

В отличие от оливина и хромшпинелида, для зерен пироксенов не характерна предпочтительная ориентировка по форме (рис.6). На гистограммах, построенных по 
данным обсчета удлинения ортопироксена во всех трех плоскостях, присутствуют многочисленные максимумы очень слабой интенсивности. Зерна пироксенов в образце распределены неравномерно, образуя сгущения на отдельных участках.

Образец шпинелевого перидотита СК103-3 отобран на некотором удалении от рудной зоны (25 м) к западу (рис.4). Он также представлен клинопироксеновым гарцбургитом, состоящим из оливина $(81,5 \%)$, ортопироксена $(14,5 \%)$, клинопироксена $(2,5 \%)$ и хромшпинелида $(1,5$ $\%)$. В отличие от описанного выше образца, перидотит СК-103-3 обладает более мелкозернистой структурой, которая представляет собой переходный тип от порфиробластовой к мозаичной. Наличие двух типов зерен - порфиробласт (>2 мм) и необласт (0,4-1,2 мм) - сохраняется во всей полноте лишь для ортопироксена, но все же последние и здесь преобладают. Для зерен оливина характерен постепенный переход в размерности зерен, которая изменяется от 0,2 до 2 мм, а в количественном отношении резко преобладают мелкие зерна со средним размером сечения 0,5-0,9 мм. В крупных зернах оливина и ортопироксена отмечаются отчетливые следы пластической деформации, аналогичные в целом описанным выше для образцов СK-103-2DA и CK-103-2L3. Для данного образца также характерной является ассоциация пироксенов и глиноземистого хромшпинелида, обычно имеющего размеры 0,05-0,2 мм.

Минеральная уплощенность в образце СК-103-3 очень четко идентифицируется в вертикальных плоскостях: оливин и агрегаты хромшпинелидов образуют совмещенные максимумы удлинения, по которым определяются элементы залегания плоскости S (аз.пад. $210^{\circ}, \angle 30^{\circ}$ ). Таким образом, она дискордантна таковой в описанных выше образцах дунита и перидотита. Линейность определяется в горизонтальной плоскости по преобладающему удлинению агрегатов хромшпинелида и, в меньшей степени, по удлинению зерен оливина (аз. склон. $135^{\circ}, \angle 25^{\circ}$ ). Хотя и в данном образце зерна ортопироксена не образуют четкой предпочтительной ориентировки по форме, она отражена в строении их агрегатов. Цепочки ортопироксена и клинопироксена ориентированы в вертикальных плоскостях согласно с ориентировкой удлинения зерен оливина и струйчатости хромшпинелида. В горизонтальной плоскости отмечается ориентировка участков, обогащенных ортопироксеном и ассоциирующими с ним зернами клинопироксена и хромшпинелида. Их удлинение образует острый угол (20$30^{\circ}$ ) с удлинением, определенным по хромшпинелиду и оливину. Наличие ориентированных существенно ортопироксеновых участков указывает, скорее всего, на то, что они образовались на месте некогда присутствовавших в породе крупных зерен энстатита, разрушенных в ходе пластической деформации вследствие их большей хрупкости по сравнению с оливином.

Образец CK-103-2LB отобран в 2 м восточнее рудовмещающего дунитового тела и примечателен тем, что в нем совмещены перидотит и большая часть тонкого (3-4 см) дунитового прожилка (рис.6). В отличие от рудовмещающего дунита и перидотита CK-103-2L3, главная структурная плоскость данного образца ориентирована почти горизонтально, согласно контакту дунит-перидотит (аз. пад. $270^{\circ}$, $\angle 10-15^{\circ}$ ). Петрографический состав перидотитовой части образца в целом сходен с таковым образца CK-103-2L3. Структурное отличие заключается в том, что минеральная уплощенность и линейность значительно лучше подчеркиваются морфологией зерен хромшпинелидов по сравнению с оливином. Последний практически не обнаруживает линейности в горизонтальной плоскости (шл.СК-103-2LB2), и неоднозначно определяется уплощенность в плоскости шл.СК-103-2LB4.

Bo всех трех плоскостях отмечены признаки высокотемпературных деформаций породообразующих минералов, а в шлифе CK-103-2LB2, кроме того, отмечаются «напряженные взаимоотношения» 
оливина и ортопироксена. Они выражены в квазихрупком разрыве зерен последнего и внедрении в ослабленные зоны фрагментированного оливина (рис.3). Ортопироксен не обнаруживает предпочтительной морфологической ориентировки зерен в пространстве, но для него характерна агрегатная ориентировка в плоскости минерального уплощения и направлении линейности.

В дунитовом прожилке в значительной мере усиливаются морфологические ориентировки для зерен оливина и хромшпинелида. Оба минерала имеют сильные максимумы в плоскостях шлифов СК-1032LB4 и CK-103-2LB5. В плоскости, параллельной контакту дунит-перидотит, линейность зерен оливина и хромшпинелида проявлена достаточно слабо (шл. CK-103-2LB7), но агрегатная линейность рудного минерала довольно отчетлива, как следует из данных рентгеновской томографии (рис.7). Кроме того, в дунитовом прожилке происходит увеличение концентрации зерен хромшпинелида по сравнению с перидотитом, а также их перераспределение в пространстве с образованием агрегатов, имеющих «разлапистые» очертания. К сожалению, невысокое разрешение томографических снимков (50 мкм) не позволяет увидеть детали морфологии отдельных зерен.

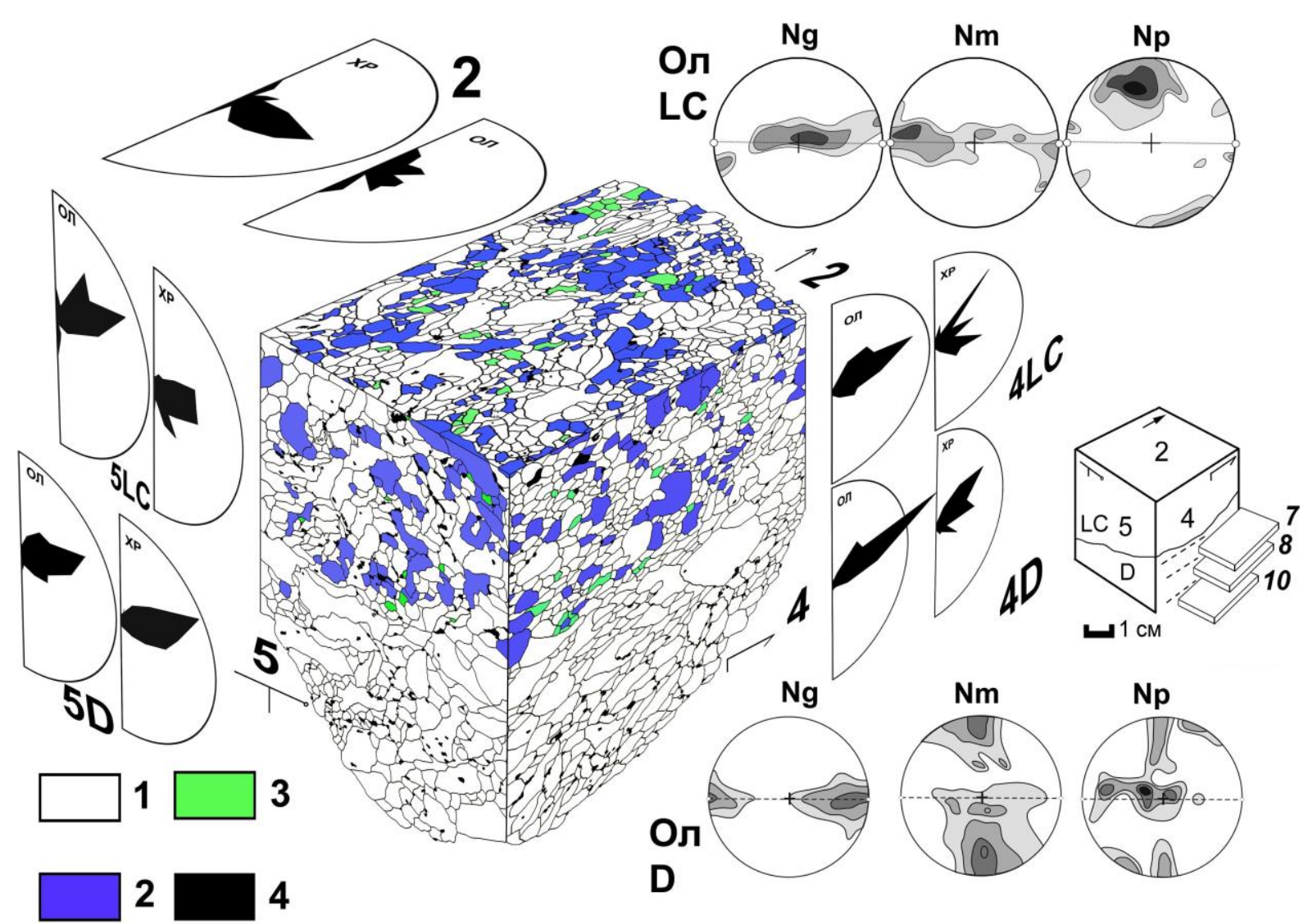

Рис.6. Блок-диаграмма образиа перидотита с дунитовым прожилком на восточном фланге месторождения: 1 - оливин, 2 - ортопироксен, 3 - клинопироксен, 4 -хромшпинелид; сокращения: ол - оливин, хр - хромшпинелид, LC - перидотит, D-дунит. Цифры на плоскостях блок-диаграммы обозначают номера шлифов, которые использованы при составлении изображений (например: CK-103-2LB-2 - для горизонтальной плоскости). На петроструктурных диаграммах показаны проекции на верхнюю полусферу сетки Шмидта, изолинии проведены через 1-2-4-8\%, исследовано по 105 зерен; диаграммы приведены методом поворота к стандартному виду 


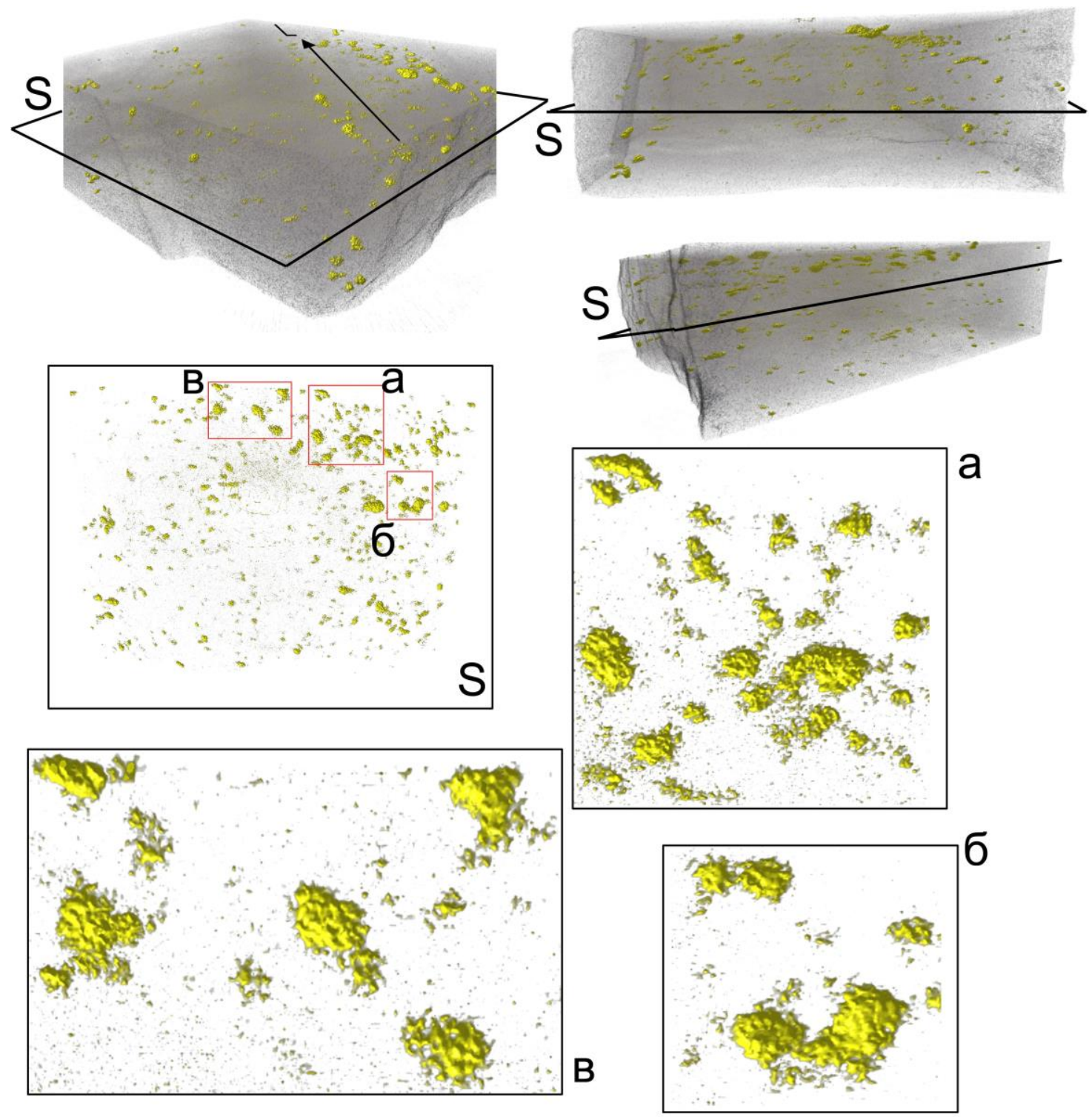

Рис.7. Объемные изображения дунитового прожилка в образие CK-103-2LB и детали строения хромшпинелидовых агрегатов в плоскости минеральной уплощенности (S). Желтым иветом показаны агрегаты зерен хромшпинелидов, серым - силикатный матрикс, представленный серпентинизированным оливином, толщина образиа 10 мм

\section{Обсуждение результатов}

Полученные геолого-структурные данные позволяют отнести изученное месторождение №33 к типично подиформным (podiform deposit). Согласно международным классификациям, оно сопоставимо с субконкордантными телами [43] или же с подтипом «одиночных подов» в типе «strings-of-pods» [46]. Применительно к уральским месторождениям, изученный объект соответствует халиловскому типу месторождений [30]. Все указанные выше варианты классификаций подобных месторождений предполагают дискордантное, но с небольшой взаимной разориентировкой расположение структурных элементов рудоносной дунитхромититовой ассоциации и окружающих перидотитов. Такие месторождения, как правило, вмещаются «дунитовыми конвертами» (dunite envelopes), отделяющими массивные крупнозернистые хромититы от перидотитов обрамления. Происхождение оруденения данного типа и околорудных дунитов проблематично объяснить с позиций магматической, метасоматической и реакционно-магматической гипо- 
тез. В подобных объектах, как ни в каких других, налицо отсутствие какого бы то ни было баланса вещества для геохимического преобразования перидотитов в рудоносную ассоциацию или для любого варианта магматической дифференциации (см. ниже).

Любое исследование, имеющее целью определение генезиса геологического объекта, сталкивается с проблемой выявления процесса (событий во времени) на основе изучения статичного материала. Один из основных путей, ведущих к преодолению данной проблемы в других областях знаний - воспроизведение природных условий в лаборатории (эксперимент) - для петрологии мантийных ультрамафитов в полной мере невозможен. Только отдельные элементарные процессы на уровне зерен и минеральных агрегатов могут быть воспроизведены в эксперименте (плавление, химическое взаимодействие, пластическая деформация). В дальнейшем, насколько возможно, мы воспользуемся имеющимися экспериментальными данными при обсуждении проблемы.

Другая возможность - выявление в изучаемых однотипных объектах различных переходных стадий одного и того же процесса, которой мы воспользуемся в полной мере. Примем следующие допущения: 1) будем рассматривать ультрамафитовые комплексы складчатых поясов как однотипные объекты, соответственно к однотипным будем относить все дунитовые образования среди перидотитов этих комплексов; 2) если предполагаемый процесс действительно имел место при образовании многих однотипных объектов, то маловероятно, что он прошел во всех случаях до конца, т. е. достаточно часто должны наблюдаться его переходные стадии; 3) процесс характеризовался некоторой длительностью, впрочем, абсолютный временной интервал этой «длительности» не важен, а важно лишь то, что процесс не мог завершиться мгновенно.
Рассмотрим, какие переходные стадии и/или результаты должны сопровождать декларируемые процессы. Ограничимся тремя простыми моделями - магматической, реакционной (включая реакционномагматическую, метасоматическую, латераль-секреционную) и реоморфической.

Образование дунитов и хромититов в результате кристаллизационной дифференциации должно сопровождаться асимметричной петрографической и геохимической зональностью, подобно таковой, устанавливаемой в расслоенных интрузиях. Для офиолитовых комплексов этот механизм приходится исключить по следующим причинам: 1) холодные тектонические контакты массивов, 2) сложные структурные соотношения между дунитхромититовой ассоциацией и перидотитами, эпигенетичность дунитовых жил по отношению к перидотитам, 3) отсутствие скрытой геохимической расслоенности, 4) несоответствие состава породообразующего оливина закономерностям кристаллизационной дифференциации: выдержанные высокие содержания магния и никеля в оливине независимы от положения пород в разрезе, тогда как кристаллизация расплава сопровождается постепенным уменьшением концентрации данных элементов в оливине вследствие высокого коэффициента их распределения между оливином и расплавом [20].

Как предполагает ряд исследователей $[14,18]$, магматическое внедрение дунитов с хромовым оруденением в твердые перидотиты должно привести к плавлению самих перидотитов, поскольку температура плавления ассоциации оливина и высокохромистого шпинелида намного превышает таковую для пироксенсодержащих ассоциаций. Присутствие флюида, которому приписывается решающая роль в понижении температуры кристаллизации остаточного рудно-силикатного расплава, фиксируется обычно не в дунитах, а в окружающих перидотитах. В частности, в изученных нами образцах месторождения №33 в перидотитах (СК-1032LB) обнаружены небольшие количества 
паргасита $(0, \mathrm{n}-2 \%)$ и зафиксирована система скольжения оливина, характерная для влажных условий деформации [24, 28].

Все реакционные модели образования дунитов с хромовым оруденением предполагают постепенный переход существенно ортопироксеновых парагенезисов в мономинеральный оливиновый, но различными способами: оливинизация при проработке магнезиальными или восстановленными флюидами $[6,17,35,36]$ либо реакция расплава базальтового или бонинитового состава с перидотитом, ведущая к растворению пироксенов $[4,48,54]$. Общей для этих моделей является длительность процесса, которая по определению должна оставлять в породах множество свидетельств переходных стадий. Мы должны всегда фиксировать постепенный переход от перидотита к дуниту, причем в зоне контакта должны встречаться химически корродированные зерна пироксенов, реакционные взаимоотношения между пироксенами и оливином, кристаллизовавшиеся неудаленные расплавные составляющие с выделившимися здесь же мелкими кристаллами хромита и т.д. Однако в реальных дунитах обычно этих признаков не наблюдается. Часть из указанных выше признаков отмечается в плагиоклазовых перидотитах, которые часто сопровождают крупные дунитовые тела [31], однако связь их с дунитами и хромититами не определена. В дунитах же, как правило, отмечается «трещинное» течение расплава, фиксируемое в виде прожилков клинопироксена, занимающих секущее положение по отношению к внутренней структуре пород (струйчатости хромшпинелидов, минеральной сланцеватости) [31].

Перейдем теперь к рассмотрению фактов, которые должны наблюдаться при реализации твердофазного механизма образования дунитов и хромититов. По определению, переход от перидотитов к дунитам здесь также должен быть посте- пенным, но реализовываться не химическим, а механическим путем [26, 27], что должно быть отражено в постепенном увеличении мощности мономинеральных прослоев поликристаллического оливина. Пироксены, препятствующие пластическому течению, должны мигрировать из центральных частей потока к краям. Неоднородная деформация породообразующих минералов должна фиксироваться петрографическими методами. Если твердофазное извлечение хрома из породообразующих минералов действительно имело место в природных ультрамафитах, то оно должно также фиксироваться петрографическими методами в образцах, где процесс был остановлен на начальной стадии образования дунитовых обособлений. Как было показано в приведенном выше фактическом материале, все необходимые факты были установлены в перидотит-дунит-хромититовой ассоциации месторождения № 33.

На основе исследования петроструктуры оливина было показано, что все породы изученного участка в момент «замораживания» процесса мантийного минералообразования находились в условиях интенсивных пластических деформаций, протекавших в режиме дислокационной ползучести [23-25]. Диагностированные в породах петроструктурные узоры оливина сопоставимы с экспериментальными данными [39, 42, 47]. Общее давление может быть оценено лишь приблизительно >7 кбар (по отсутствию плагиоклаза), оценки температур дают наиболее вероятный интервал 800-1000 ${ }^{\circ} \mathrm{C}$, содержание воды в образце CK-103-2LB, деформированном в наиболее влажных условиях, оценивается в $>200 \mathrm{ppm} \mathrm{H} / \mathrm{Si}$ и величина стресса $>400$ МПа [24]. При этом максимальный стресс (и/или скорость деформации) всегда связан с мономинеральными оливиновыми агрегатами (дунитами) [22, 24]. 

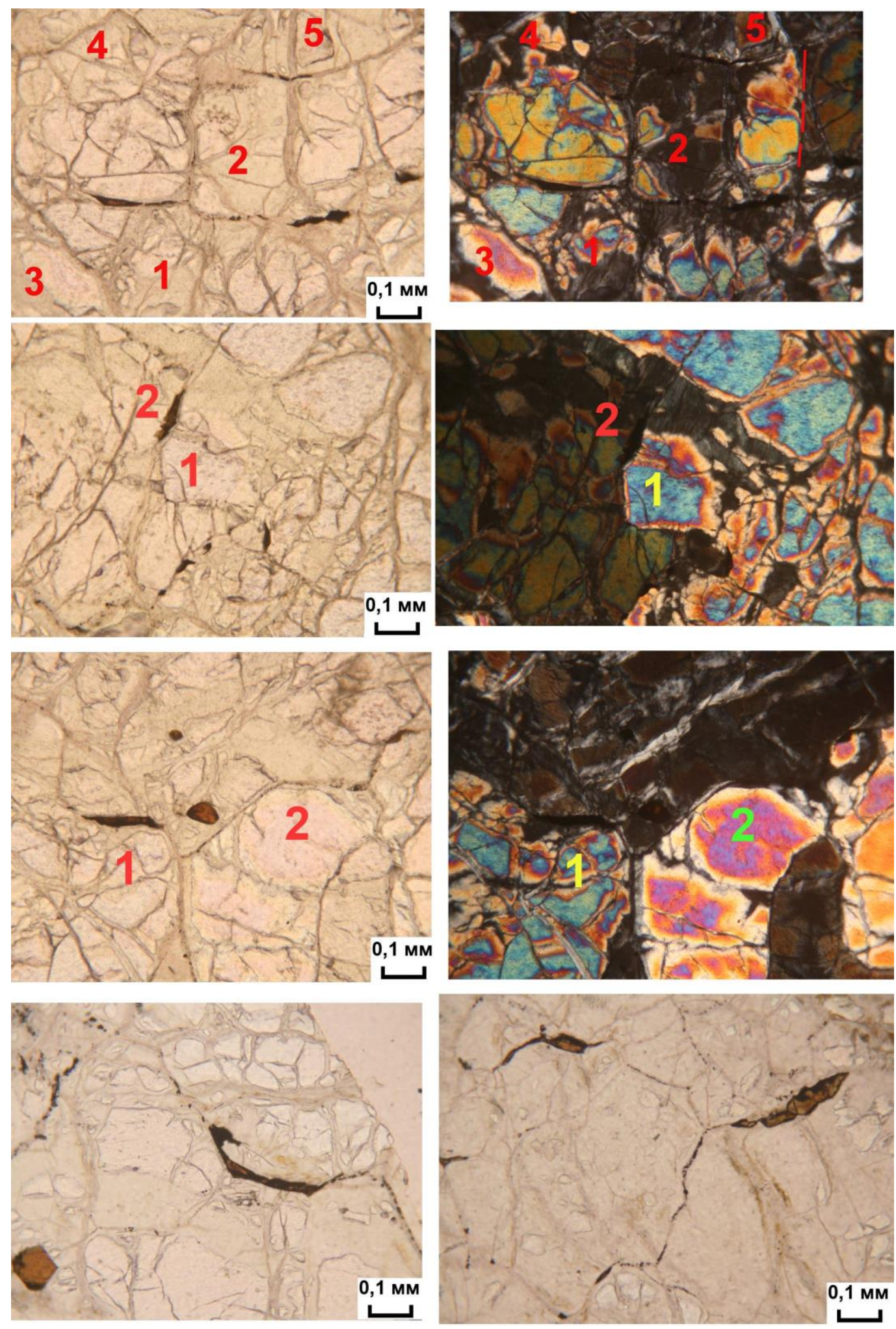

Рис.8 Нитевидные выделения хромшпинелида на границах пластически деформированных зерен оливина в дунитовой части образиа CK-103-2LB (илиф CK-103-2LB7). Фотографии сделаны в проходямем плоскополяризованном свете при выключенном (слева и внизу) и включенном (справа) анализаторе. Пара снимков в каждом горизонтальном ряду отражсает строение одних и тех же участков, цифрами обозначены одни и те же места на каждом снимке ряда. $B$ нижнем ряду - два различных участка 
Согласно модели, разработанной в [26, 27], дуниты трассировали зоны наибольшей скорости пластического течения, в которых менее мобильные зерна пироксенов мигрировали в краевые части, обогащая их (пример - обр. CK-103-2L3 и CK103-2LB). В обоих образцах между оливином и ортопироксеном наблюдаются четкие признаки механического взаимодействия: ортопироксен деформируется разрывом квазихрупко, а оливин - пластически, заполняя ослабленные зоны. Исследование объемного строения инициального дунитового прожилка позволило установить следующие факты: 1) сегрегирование зерен хромшпинелидов в плоскости минеральной сланцеватости дунита; 2) увеличение содержания рудного минерала; 3) перераспределение его в пространстве с формированием микроскопических рудных агрегатов.

Петрографические исследования шлифов, ориентированных в плоскости минерального уплощения, которая является параллельной контакту дунит-перидотит, позволили обнаружить новообразованные выделения хромшпинелидов на границах пластически деформированных зерен оливина. Таким образом, выявляется однозначная связь этих выделений с высокотемпературными деформациями ультрамафитов и образованием дунитового прожилка в перидотите, т. е. с самой начальной стадией формирования мономинерального оливинового обособления.

Наиболее ранними выделениями хромшпинелидов, которые могут быть диагностированы оптическими методами, являются $10 *$ n-микронные пылевидные частицы на границах зерен (реже - субзерен) деформированного оливина, которые чаще всего встречаются в виде нитевидных сегрегаций (рис.8). Указания на возможность реализации подобных механизмов в геологических средах содержатся в ряде публикаций, посвященных петрологии мантийных ультрамафитов [8, 13,31 , 40]. В литературе есть указания на экспериментально воспроизведенную сегрега- цию примеси марганца из зерен оливина при деформации последнего [44].

Наблюдаемые факты интерпретируются по аналогии с пластической деформацией металлов и сплавов как процессы деформационно-индуцированного выделения дисперсных фаз, в данном случае хромшпинелида. Причина выделений нахождение твердого раствора данного состава в двухфазной области диаграммы состояния, эта область увеличивается для большинства соединений в условиях деформации [9 и др.], причем, возможны когерентный и некогерентный варианты распада. В геологических объектах обычно диагностируется только первый вариант, примеры его достаточно хорошо известны (ламелли диопсида в ортопироксене и др.). Однако в случае оливина и хромшпинелида кристаллические решетки минералов не совпадают, и поэтому происходит некогерентный распад твердого раствора. Как показывают исследования пластического деформирования металлов и сплавов, два упомянутых варианта распада твердого раствора оказывают различное влияние на пластическое течение: когерентные структуры всегда ведут к упрочнению кристаллов матрикса, тогда как некогерентные почти не влияют на характер деформации и даже способствуют пластическому течению, если дисперсные фазы склонны к коалесценции [9]. По-видимому, именно последний вариант демонстрирует изученный образец ультрамафита. Нитевидные выделения хромшпинелидов сливаются в определенных центрах (рис.9), причем такое слияние часто сопровождается растворением рудного вещества в промежуточных частях сегрегаций (рис.9). Эта особенность хорошо объясняется следующим образом: движущей силой коалесценции является минимизация поверхностной и зернограничной свободных энергий, поэтому выделения меньше критического размера неустойчивы, они поглощаются более крупными и устойчивыми сегрегациями. 

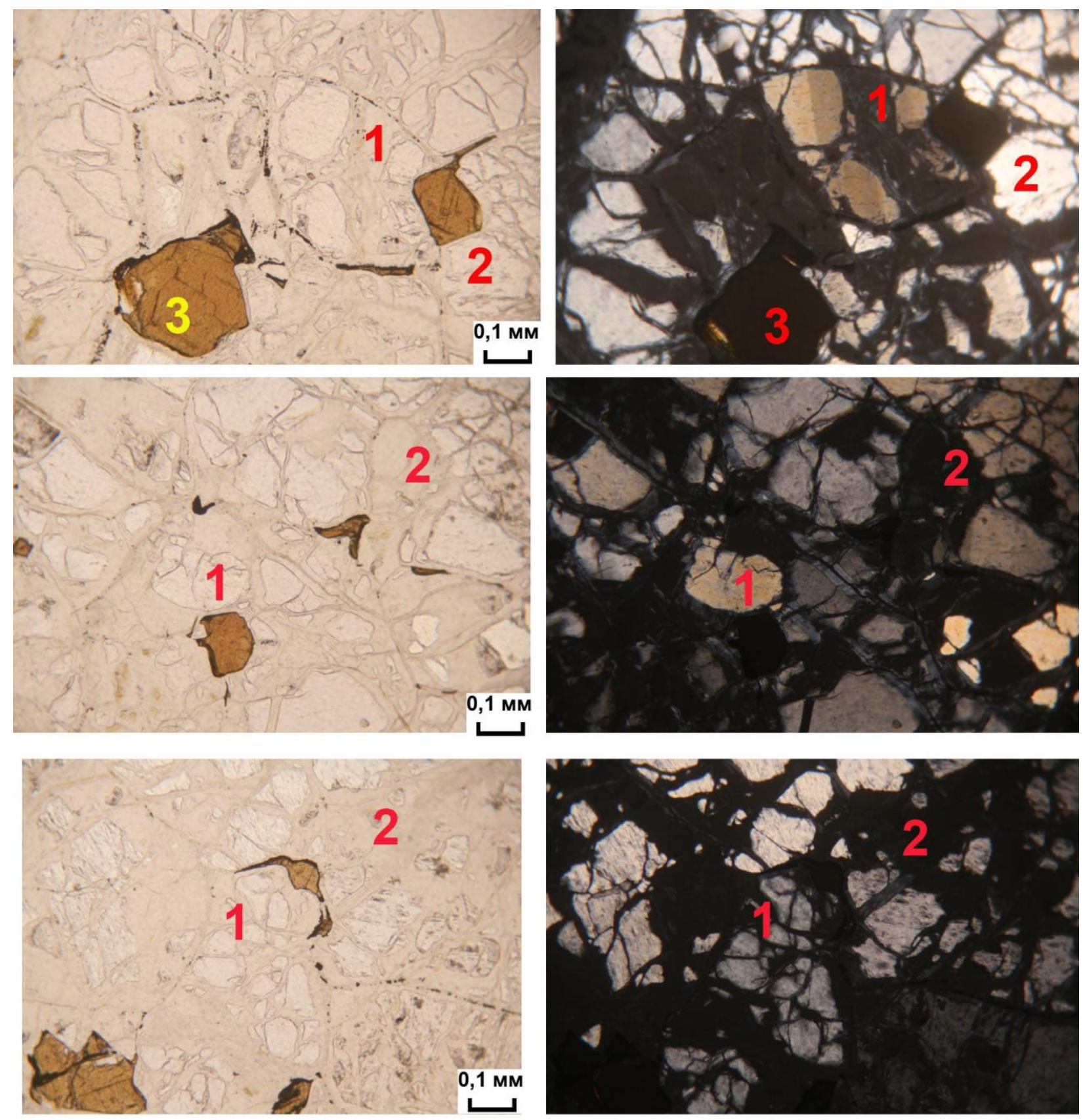

Рис.9. Коагуляиия выделений хромипинелидов в дунитовом прожилке (илифы CK-103-2LB7, CK-103-2LB9, CK-103-2LB10). Фотографии сделаны в проходящем плоскополяризованном свете при выключенном (слева) и включенном (справа) анализаторе. Пара снимков в каждом горизонтальном ряду отражает строение одних и тех же участков, ичиррами обозначены одни и те же места на каждом снимке ряда

Следующей стадией образования идиоморфных кристаллов хромшпинелидов, столь характерных для офиолитовых дунитов, является сфероидизация выделений, которая чаще всего заключается в стремлении дисперсных фаз к образованию кристаллографически правильных форм (рис.10). Данный процесс хорошо известен в металлургии при пластической деформации металлических материалов [5]. Движущей силой в этом случае также является минимизация зернограничной свободной энергии. Сформированные таким образом мелкие идиоморфные кри- 
сталлы хромшпинелидов при продолжающемся пластическом течении сегреги-
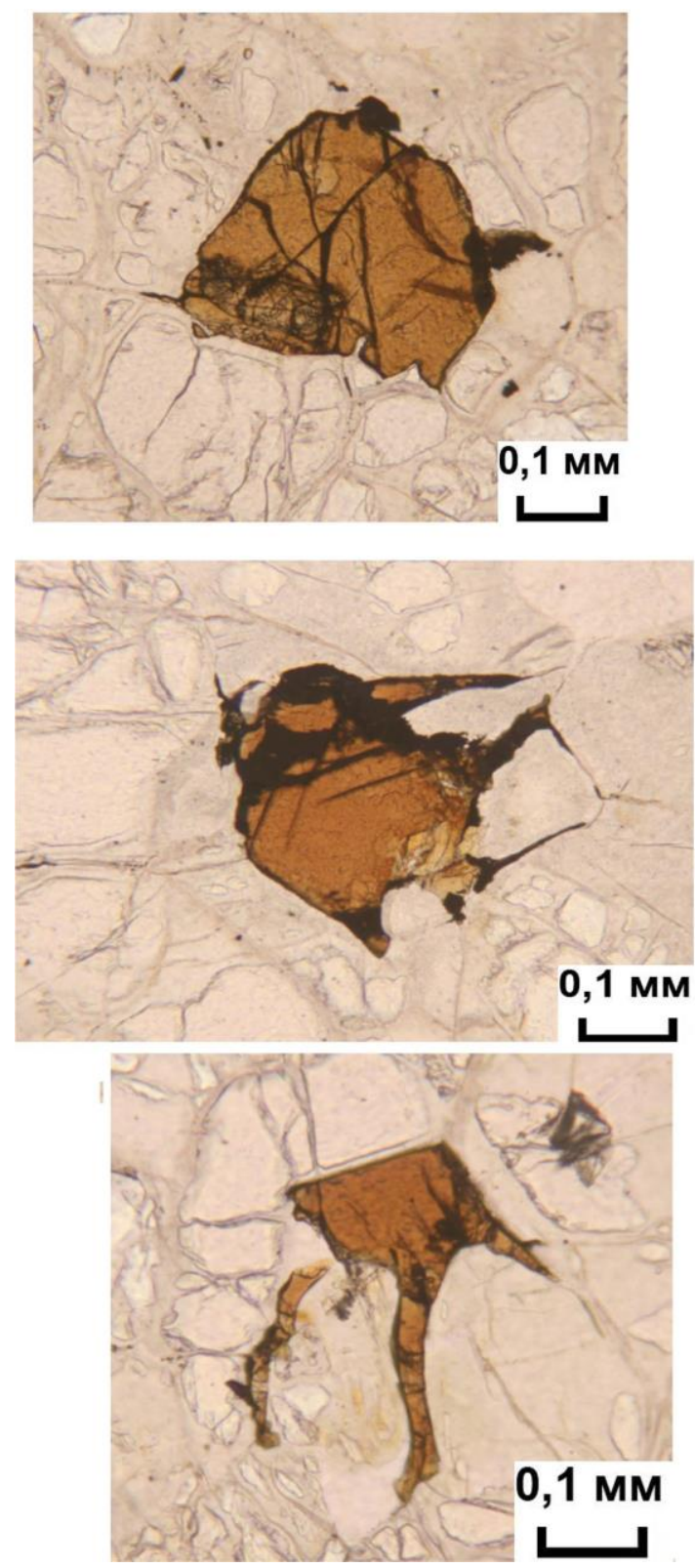

руют в рудные агрегаты одновременно с увеличением мощности дунитовых тел.
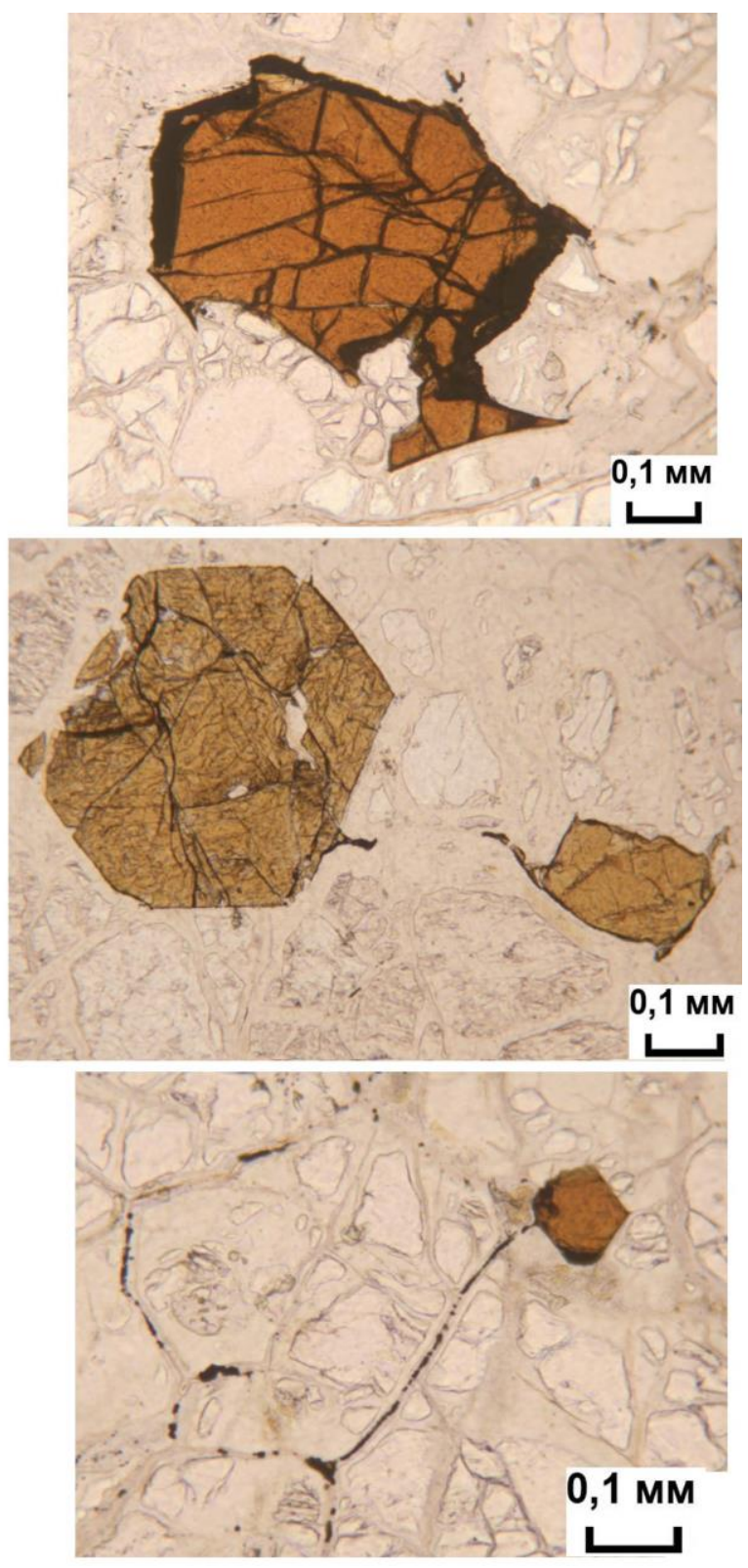

Рис.10. Коагуляция и сфероидизация выделений хромшпинелидов в дунитовом прожилке (илифы $C K-103-2 L B 7, C K-103-2 L B 9, C K-103-2 L B 10)$

Таким образом, обсуждение трех различных моделей формирования дунитов и связанного с ними хромового оруденения на базе представленного в работе фактического материала показало, что имеющиеся факты подтверждают реализацию только одного из рассмотренных механизмов - твердофазной (реоморфической) сегрегации вещества внутри мантийного

\section{Выводы}

Проведенные структурные, рентгенотомографические и петрографические исследования ультрамафитов участка «месторождение №33» на массиве Средний Крака позволяют сформулировать следующие выводы. 
1. Исследование объемного строения инициального дунитового прожилка позволило установить факт сегрегирования зерен хромшпинелидов в плоскости минеральной сланцеватости дунита, увеличение содержания рудного минерала и перераспределение его в пространстве с формированием микроскопических рудных агрегатов.

2. Петрографические исследования позволили обнаружить в дунитовом прожилке новообразованные выделения хромшпинелидов. Начальные стадии сегрегации проявляются в образовании нитевидных выделений вдоль границ пластически деформированных зерен оливина, которые в дальнейшем сливаются, формируя кристаллографически ограненные кристаллы. Выявленные в природных образцах структуры по генезису представляют собой аналоги таковых, образующихся в условиях динамического старения металлов, и обусловлены реоморфической сегрегацией примесей.

3. Тело хромититов месторождения №33 образовалось в результате высокотемпературного вязкопластического течения ультрамафитов, в результате того же процесса, который сформировал структуру вмещающих пород. Факты обогащения пироксенами прилегающих к дунитам участков шпинелевых перидотитов находятся в хорошем соответствии с реоморфической моделью генезиса хромититов.

Авторы признательны руководству Лаборатории ядерных проблем ОИЯИ за возможность изучения ультрамафитов на рентгеновском томографе MARS; Д.Ю. Нестериу и сотрудникам ИГ УНЦ РАН В.И. Сначеву, Е.А. Бажину, Д.Г. Ширяеву, А.В. Лёшину за содействие в проведении полевых исследований и подготовке ориентированных образцов.

Работа выполнена при поддержке гранта «РФФИ-Поволжье», проект «№14-05-97001 р_повольжье_а»

\section{Библиографический список}

1.Алимов В.Ю. Механизм дифференциации вещества при сдвиговых деформациях зернистых сред (в приложении к хромитообразованию) //Ежегодник-93. Свердловск, 1994. С. 64-65.

2.Алимов В.Ю. Деформационный механизм формирования хромитового оруденения в альпинотипных гипербазитах // Рудогенез. Миасс; Екатеринбург, 2008. С. 4-7.

3.Бакиров А.Г. О происхождении дунитов и хромитов Кемпирсайского массива // Магматизм, метаморфизм, металлогения Урала. Свердловск, 1963. С. 325 - 330.

4.Батанова В.Г., Савельева Г.Н. Миграция расплавов в мантии под зонами спрединга и образование дунитов замещения: обзор проблемы // Геология и геофизика. 2009. T.50, №9. C. 992-1012.

5.Бунин К.П., Баранов А.А. Металлография. М.: Металлургия, 1970. 312 с.

6.Варлаков А.С. Генезис хромитового оруденения в альпинотипных гипербазитах Урала // Петрография ультраосновных и щелочных пород Урала. Свердловск, 1978a. C. 63 - 82.

7.Вахрушева Н.В., Алимов В.Ю. О локальной изменчивости спектров редкоземельных элементов в хромитоносных ультрамафитах Полярного Урала // Литосфера. 2014. № 1. С. 41-57.

8.Гончаренко А.И. Деформация и петроструктурная эволюция альпинотипных гипербазитов. Томск: Изд-во Том. ун-та, 1989. $404 \mathrm{c}$.

9.Горелик С.С. Рекристаллизация металлов и сплавов. М.: Металлургия, 1978. 568 с.

10. Денисова Е.А. Строение и деформационные структуры офиолитовых массивов с лерцолитовым типом разреза // Геотектоника. 1990. № 2. С. 14-27.

11. Казаков А.Н. Динамический анализ микроструктурных ориентировок минералов. Л.: Наука, 1987. 272 с.

12. Кравченко Г.Г. Роль тектоники при кристаллизации хромитовых руд Кемпирсайского плутона. М.: Наука, 1969. 232 с.

13. Кутолин В.А. Перекристаллизация вещества верхней мантии и ее металлогенические следствия // Мантийные ксенолиты и проблема ультраосновных магм. Новосибирск: Наука, 1983. С. 17-22. 
14. Логинов В.П., Павлов Н.В., Соколов Г.А. Хромитоносность Кемпирсайского ультраосновного массива на Южном Урале // Хромиты СССР. М.; Л.: Изд-во АН СССР, 1940. T. 2. C. 5-199.

15. Лукин Л.И., Чернышев В.Ф., Кушнарев И.П. Микроструктурный анализ. М.: Наука, 1965. 124 с.

16. Макеев А.Б., Брянчанинова Н.И. Топоминералогия ультрабазитов Полярного Урала. СПб.: Наука, 1999. 252 с.

17. Москалёва С.В. Гипербазиты и их хромитоносность. Л.: Недра, 1974. 279 с.

18. Павлов Н.В., Григорьева-Чупрынина И.И. Закономерности формирования хромитовых месторождений. М.: Наука, 1973. 199 c.

19. Павлов Н.В., Григорьева И.И., Гришина H.B. Образование и генетические типы хромитовых месторождений геосинклинальных областей // Условия образования магматических рудных месторождений. М.: Наука, 1979. С. 5-78.

20. Рингвуд A.E. Состав и петрология мантии Земли. М.: Недра, 1981. 585 с.

21. Савельев A.A. Хромиты ВойкароСыньинского массива // Генезис ультрабазитов и связанного с ними оруденения. Свердловск, 1977. С. 63-77.

22. Савельев Д.Е. Соотношение структур рудоносной дунит-хромититовой ассоциации и перидотитов в офиолитах (на примере массивов Крака) // Литосфера. 2013. №2. C.76-91.

23. Савельев Д.Е. Происхождение нодулярных текстур (на примере хромититов восточной части массива Средний Крака, Южный Урал) // Руды и металлы. 2013. №5. C. 41-49.

24. Савельев Д.Е. О реоморфической дифференциации вещества ультрамафитов (на примере месторождения №33, Средний Крака) // Геологический сборник / ИГ УНЦ РАН. Уфа, 2013. № 10. С. 241-256.

25. Савельев Д.Е. К вопросу о происхождении пойкилитовых включений оливина в хромшпинелидах из офиолитовых дунитов // Геологический сборник. Уфа: ДизайнПресс, 2014. №11. С. 134-146.

26. Савельев Д.Е., Федосеев В.Б. Сегрегационный механизм формирования тел хромититов в ультрабазитах складчатых поясов // Руды и металлы. 2011. №5. С. 35-42.
27. Савельев Д.Е., Федосеев В.Б. Пластическое течение и реоморфическая дифференциация вещества в мантийных ультрамафитах // Вестник Пермского университета. Геология. 2014. №4. С. 22-41.

28. Савельев Д.Е., Белогуб Е.В., Котляров В.А. Минералого-геохимическая зональность и деформационный механизм формирования хромитит-дунитовых тел в офиолитах (на примере массива Крака, Южный Урал) // Металлогения древних и современных океанов-2014. Двадцать лет на передовых рубежах геологии месторождений полезных ископаемых / Имин УрО РАН. Миасс, 2014. C. 95-98.

29. Савельев Д.Е., Савельева Е.Н., Сначев В.И., Романовская М.А., Бажин Е.А. Эволюция процессов хромитообразования в альпинотипных гипербазитах // Бюл. Моск. о-ва испытат. природы. 2011. Т. 86, №1. C. 31-40.

30. Савельев Д.Е., Сначев В.И., Бажин Е.А., Романовская М.A. К проблеме типизации хромитовых месторождений Южного Урала // Руды и металлы. 2009. №5. С. 512.

31. Савельев Д.Е., Сначев В.И., Савельева E.Н., Бажин Е.A. Геология, петрогеохимия и хромитоносность габброгипербазитовых массивов Южного Урала. Уфа: ДизайнПолиграфСервис, 2008. 320 с.

32. Саранчина Г.М., Кожевников В.Н. Федоровский метод (определение минералов, микроструктурный анализ). Л.: Недра, $1985.208 \mathrm{c}$.

33. Селиванов Р.А. Условия локализации хромового оруденения в ультрамафитовых массивах Рай-Из и Войкаро-Сыньинский: дис. ... канд. геол.-мин. наук. Екатеринбург, 2011. $166 \mathrm{c.}$

34. Соколов Г.А. Хромиты Урала, их состав, условия кристаллизации и закономерности распространения // Тр. ИГН АН СССР. Сер. рудн. м-ний. Вып. 97, № 12. М.: Изд-во АН СССР, 1948. 128 с.

35. Чащухин И.С., Вотяков С.Л. Поведение элементов семейства железа, оксибарометрия и генезис уникальных хромитовых месторождений Кемпирсайского массива // Геология рудных месторождений. 2009. T. 51, № 2. C. 140-156.

36. Чамухин И.С., Вотяков С.Л., Щапова Ю.В. Кристаллохимия хромшпинели и окситермобарометрия ультрамафитов 
складчатых областей / ИГиГ УрО РАН. Екатеринбург, 2007. 310 с.

37. Чернышов А.И. Идентификация плоскостных и линейных структурных элементов в динамометаморфизованных ультрамафитах // Динамометаморфизм и петроструктурная эволюция пород мафитультрамафитовой ассоциации. Томск, 1996. С. 99-101.

38. Чернышов А.И., Юричев А.Н. Петроструктурная эволюция ультрамафитов Калнинского хромитоносного массива в Западном Саяне // Геотектоника. 2013. № 4. C. 31-46.

39. Щербаков С.А. Пластические деформации ультрабазитов офиолитовой ассоциации Урала. М.: Наука, 1990. 120 с.

40. Ярош П.Я. О первоисточнике хрома в дунитах и природе акцессорного хромита // Записки ВМО. 1980. Ч. 109, вып. 1. С. 98105.

41. Ballhaus $C$. Origin of the podiform chromite deposits by magma mingling // Earth and Planetary Science Letters. 1998. Vol.156, № 3-4. P. 185-193.

42. Carter N.L. Steady state flow of rocks // Rev. Geophys. and Space Phys. 1976. Vol. 14, № 3. P. 301-360.

43. Cassard D., Nicolas A., Rabinowitch M., Moutte J., Leblanc M., Prinzhoffer A. Structural Classification of Chromite Pods in Southern New Caledonia // Econ. Geology. 1981. Vol. 76. P. 805-831.

44. Chapman $Y$. Dislocations in the deformation of olivine // Amer. J. Sci. 1969. Vol. 267. P. 841-852.

45. Greenbaum $D$. The chromitiferous rocks of the Troodos ophiolite complex, Cyprus // Econ.Geol. 1977. Vol. 72. P. 1175-1194.

46. Hock M., Friedrich G. Structural features of ophiolitic chromitites in the Zambales Range,
Luzon, Philippines // Mineralium-Deposita. 1985, Vol. 20, P. 290-301.

47. Karato S.-I., Jung H., Katayama I., Skemer $P h$. Geodynamic significance of seismic anisotropy of the upper mantle: new insights from laboratory studies // Annu. Rev. Earth Planet. Sci. 2008. Vol. 36. P. 59-95.

48. Kelemen P. B., Shimizu N., Salters V. J. M. Extraction of mid-ocean-ridge basalt from the upwelling mantle by focused flow of melt in dunite channels // Nature. 1995. Vol. 375. P. 747-753.

49. Lago B.L., Rabinowicz M., Nicolas A. Podiform chromite ore bodies: a genetic model // J. Petrology. 1982. Vol. 23, № 1. P. 103-125.

50. Leblanc M., Ceuleneer G. Chromite crystallization in a multicellular magma flow: evidence from a chromitite dike in the Oman ophiolite // Litos. 1992. Vol. 27. P. 231-257.

51. Matveev S. Ballhaus $C$. Role of water in the origin of podiform chromitite deposits // Earth and Planetary Science Letters. 2002. Elsevier, 203. P. 235-243.

52. Nicolas A., Bouchez J.L., Boudier F., Mercier J.C. Textures, structures and fabrics due to solid state flow in some European lherzolites // Tectonophysics. 1971. Vol. 12. P. 55-86.

53. Thayer T. $P$. Principal features and origin of podiform chromite deposits, and some observations on the Guleman-Soridag District, Turkey. // Econ. Geol. 1964. Vol. 59. P. 1497-1524.

54. Zhou M.-F., Robinson P.T., Malpas J., Li Z. Podiform Chromitites in the Luobusa Ophiolite (SouthernTibet): Implications for MeltRock Interaction and Chromite Segregation in the Upper Mantle // J. Petrology. 1996. Vol. 37, N. 1. P. 3-21. 


\title{
Textural and Petrographic Features of Ultramafic Rocks within Area of "Deposit \#33", Eastern Part of Sredniy Kraka Massif (South Urals)
}

\author{
D.E. Saveliev ${ }^{a}$, D.A. Kozhevnikov ${ }^{b}$ \\ ${ }^{a}$ Institute of Geology, Ufa Scientific Center RAS, 16/2 K. Marx Str., Ufa \\ 450077, Russia.E-mail:sav171@mail.ru \\ bJoint Institut for Nuclear Research , 6 Joliot-Curie Str., Dubna 141980, Russia. \\ E-mail: dkozhevn@jinr.ru
}

This article presents the results of a petrographic and X-ray tomographic structural study of the chrome bearing ultramafic rocks. It is shown that formation of the ore-grade chromite concentration is controlled by the solid-phase (rheomorphic) re-distribution of the mantle material under a visco-plastic flow. The structures developed at early stages of dunite formation are investigated on example of the fine veinlets within peridotite. It is shown that new grains of chrome spinellids in dunite form under deformation induced segregation of chrome from the olivine grains. At first, the ultrafine particles of chrome spinellids and their thready aggregates appears on the surface of deformed olivine grains. Then, the coalescence and spheroidation of these aggregates continue the transformation process. The analogy of observed structures with those developed under plastic deformation of metals and alloys is noted.

Keywords: ultramafic rocks; chromitite; plastic deformation; olivine fabric; segregation; coalescence; rheomorfism; the South Urals; Kraka.

\section{References}

1. Alimov V.Yu. 1994. Mekhanizm differetsiatsii veshchestva pri sdvigovykh deformatsiyakh zernistykh sred ( $\mathrm{v}$ prilozhenii $\mathrm{k}$ khromitoobrazovaniyu) [Mechanism of material differentiation under shear deformation of grained medium (applied to chromite formation)]. In Yezhegodnik-93. Sverdlovsk, pp. 64-65. (in Russian)

2. Alimov V.Yu. 2008. Deformatsionnyy mekhanizm formirovaniya khromitovogo orudeneniya $\mathrm{v}$ alpinotipnykh giperbazitakh [Deformation mechanism of the chromite mineralization formation in alpinotype hyperbasic rocks]. In Rudogenez. MiassYekaterinburg, pp. 4-7. (in Russian)

3. Bakirov A.G. 1963. O proiskhozhdenii dunitov i khromitov Kempirsayskogo massiva [About origin of dunites and chromites of the Kempirsayskiy massif]. In Magmatizm, metamorfizm, metallogeniya Urala. Sverdlovsk, pp. 325-330. (in Russian)
4. Batanova V.G., Savelyeva G.N. 2009. Migratsiya rasplavov $\mathrm{v}$ mantii pod zonami spredinga I obrazovanie dunitov zameshcheniya: obzor problem [Mantle melt migration beneath the spreading zones and formation of the substitution dunites: problem review]. Geologiya i geofizika, 50 (9): 992-1012. (in Russian)

5. Bunin K.P., Baranov A.A. 1970. Metallografiya [Metallography]. Metallurgiya, Moskva, 312 p. (in Russian)

6. Verlakov A.S. 1978. Genezis khromitovogo orudeneniya $\mathrm{v}$ alpinotipnykh giperbazitakh Urala [Genesis of chromite mineralization in the alpinotype hyperbasic rocks of Urals]. In Petrografiya ultraosnovnykh i shchelochnykh porod Urala. Sverdlovsk, pp. 63-82. (in Russian)

7. Vakhrusheva N.V., Alimov V.Yu. 2014. O lokalnoy izmenchivosti spektrov redkozemelnykh elementov v khromitonosnykh ultramafitakh Polyarnogo Urala [About the local variation of the rare-earth elements spectra in chromitiferous ultramafic rocks of the 
Arctic Urals]. Litosfera, 1: 41-57. (in Russian)

8. Goncharenko A.I. 1989. Deformatsiya I petrostrukturnaya evolyutsiya alpinotipnykh giperbazitov [Deformation and petro-structural evolution of alpinotype hyperbasic rock]. Izd. Tomskogo universiteta. Tomsk, 404 p. (in Russian)

9. Gorelik S.S. 1978. Rekristallizatsiya metallov i splavov [Recrystallization of metals and alloys]. Metallurgiya, Moskva, 568 p. (in Russian)

10. Denisova E.A., 1990. Stroenie i deformatsionnye struktury ofiolitovykh massivov $\mathrm{s}$ lertsolitovym tipom razreza [Composition and deformation structures of the ophiolite massifs with a lherzolite type of crosssection]. Geotektonika, 2: 14-27. (in Russian)

11. Kazakov A.N. 1987. Dinamicheskiy analiz mikrostrukturnykh orientirovok mineralov [Dynamic analysis of minerals microstructural orientation]. Nauka, Leningrad, 272 p. (in Russian)

12. Kravchenko G.G. 1969. Rol tektoniki pri kristallizatsii khromitovykh rud Kempirsayskogo plutona [Role of tectonics in crystallization of chromite ore of the Kempirsayskiy Pluton]. Nauka, Moskva, 232 p. (in Russian)

13. Kutolin V.A. 1983. Perekristallizatsiya veshchestva verkhney mantii i eyo metallogenicheskie sledstviya [Recrystallization of an upper mantle material and its metallogenic consequences]. In Mantiynye ksenolity I problema ultraosnovnykh magm, pp.17-22. (in Russian)

14. Loginov V.P., Pavlov N.V., Sokolov G.A. 1940. Khromitonosnost Kempirsayskogo ultraosnovnogo massiva na Yuzhnom Urale [Chromite content of the Kempirsayskiy ultrabasic massif at the South Urals]. In Chromites of SSSR, T. 2, Izd. AN SSSR, MoskvaLeningrad pp. 5-199. (in Russian)

15. Lukin L.I., Chernyshev V.F., Kushnarev I.P. 1965. Mikrostrukturnyy analiz [Microstructural analysis]. Nauka, Moskva, 124 p. (in Russian)

16. Makeev A.B., Bryanchaninova N.I. 1999. Topomineralogiya ultrabazitov Polyarnogo Urala [Topo-mineralogy of ultrabasic rocks of the Arctic Urals]. Nauka, St.-Peterburg, 252 p. (in Russian)

17. Moskalyova S.V. 1974. Giperbazity i ikh khromitonosnost [Hyperbasic rocks and their chromitiferousness. Nedra, Leningrad, 279 p. (in Russian)

18. Pavlov N.V., Grigoryeva-Chuprynina I.I. 1973. Zakonomernosti formirovaniya khromitovykh mestorozhdeniy [Mechanism of the chromite deposits formation]. Nauka, Moskva, 199 p. (in Russian)

19. Pavlov N.V., Grigoryeva I.I., Grishina N.V. 1979. Obrazovanie i geneticheskie tipy khromitovykh mestorozhdeniy geosinklinalnykh oblastey [Formation and genetic types of chromite deposits of the geosinclinal areas]. In Usloviya obrazovaniya magmaticheskikh rudnykh mestorozhdeniy. Nauka, Moskva, pp. 5-78. (in Russian)

20. Ringwood A.E. 1969. Composition and evolution of the upper mantle. In The Earth's Crust and Upper Mantle (P.J. Hart Ed.). Am. Geophys. Union, Washington D.C., pp. 1-17.

21. Saveliev A.A. 1977. Khromity VoykaroSynyinskogo massiva [Chromites of the Vaykaro-Synyinskiy massif]. In Genezis ultrabazitov i svyazannogo s nimi orudeneniya. Sverdlovsk, pp. 63-77. (in Russian)

22. Saveliev D.E. 2013. Sootnoshenie struktur rudonosnoy dunit-khromititovoy assotsiatsii i peridotitov $\mathrm{v}$ ofiolitakh (na primere massivov Kraka) [Relationship between the structures of ore-bearing dunite-chromitite association and peridotites in the ophiolites (on the example of Kraka massifs)]. Litosfera, 2: 7691. (in Russian)

23. Saveliev D.E. 2013. Proiskhozhdenie nodulyarnykh tekstur (na primere khromititov vostochnoy chasti massiva Sredniy Kraka, Yuzhnyy Ural) [Nature of the nodular textures (on the example of chromitites of the eastern part of Sredniy Kraka massif, South Urals)]. Rudy i metally. 5: 41-49. (in Russian)

24. Saveliev D.E. 2013. O reomorficheskoy differentsiatsii veshchestva ultramafitov (na primere mestorozhdeniya \#33, Sredniy Kraka) [About rheomorphic differentiation of the ultramafic material (on the example of Deposit \#33, Sredniy Kraka)]. Geologicheskiy sbornik, 10: 241-256. (in Russian)

25. Saveliev D.E. 2014. K voprosu o proiskhozhdenii poykilitovykh vklyucheniy olivine $\mathrm{v}$ khromshpinelidakh iz ofiolitovykh dunitov [On the problem of origin of the poikilitic inclusions from ophiolite dunites]. Geologicheskiy sbornik. 11: 134-146. (in Russian) 
26. Saveliev D.E., Fedoseev V.B. 2011. Segregatsionnyy mekhanizm formirovaniya tel khromititov $\mathrm{v}$ ultrabazitakh skladchatykh poyasov [Segregation mechanism of chromitite body formation in the ultrabasic rocks of fold belts]. Rudy i metally, 5: 35-42. (in Russian)

27. Saveliev D.E., Fedoseev V.B. 2014. Plasticheskoe techenie i reomorficheskaya differentsiatsiya veshchestva $\mathrm{v}$ mantiynykh ultramafitakh [Plastic flow and rheomorphic differentiation of the mantle ultramafic rocks]. Vestnik Permskogo universiteta. Geologiya, 4: 22-41. (in Russian)

28. Saveliev D.E., Belogub E.V., Kotlyarov V.A. 2014. Mineralogo-geokhimicheskaya zonalnost i deformatsionnyy mekhanizm formirovaniya khromiti-dunitovykh tel $\mathrm{v}$ ofiolitakh (na primere massiva Kraka, Yuzhnyy Ural) [Mineral-geochemical zonation and deformation mechanism of formation of chromitite-dunite bodies in ophiolites (on the example of Kraka massif, South Urals)]. In Metallogeniya drevnikh i sovremennykh okeanov - 2014. Dvadtsat let na peredovykh rubezhakh geologii mestorozhdeniy poleznykh iskopaemykh. Imin UrO RAN, Miass, pp. 95-98. (in Russian)

29. Saveliev D.E., Savelieva E.N., Snachev V.I., Romanovskaya M.A., Bazhin E.A. 2011. Evolutsiya protsessov khromitoobrazovaniya $\mathrm{v}$ alpinotipnykh giperbazitakh [Evolution of processes of chromite formation in the alpinotype hyperbasic rocks]. Byulleten Moskovskogo obshchestva ispytateley prirody, 86 (1): 31-40. (in Russian)

30. Saveliev D.E., Snachev V.I., Bazhin E.A., Romanovskaya M.A. 2009. K probleme tipizatsii khromitovykh mestorozhdeniy $\mathrm{Yu}$ zhnogo Urala [On the problem of typification of the South Urals chromite deposits]. Rudy i metally, 5: 5-12. (in Russian)

31. Saveliev D.E., Snachev V.I., Savelieva E.N., Bazhin E.A. 2008. Geologiya, petrogeokhimiya i khromitonosnost gabbrogiperbazitovykh massivov Yuzhnogo Urala [Geology, petrogeochemistry, and chromite content of gabbro-hyperbasic massifs of the South Urals]. DisignPoligrafServis, Ufa, 320 p. (in Russian)

32. Saranchina G.M., Kozhevnikov V.N. 1985. Fedorovskiy metod (opredelenie mineralov, mikrostrukturnyy analiz) [Fedorovskiy meth- od (minerals definition, microstructural analysis)]. Nedra, Leningrad, 208 p. (in Russian)

33. Selivanov R.A. 2011. Usloviya lokalizatsii khromovogo orudeneniya $\mathrm{v}$ ultramafitovykh massivakh Ray-Iz i Vaykaro-Synyinskiy [Conditions of localization of the chrome ores in ultramafic massifs Ray-Iz and Vaykaro-synyinskiy]. Diss. cand. geol.-min. nauk, Yekaterinburg, 166 p. (in Russian)

34. Sokolov G.A. 1948. Khromity Urala, ikh sostav, usloviya kristallizatsii I zakonomernosti rasprostraneniya [Chromites of Urals, their composition, crystallization conditions, and regularities of distribution]. Trudy IGN AN SSSR, V. 97; Ser. Rudn. Mestor., 12, 128 p. (in Russian)

35. Chashchukhin I.S., Votyakov S.L. 2009. Povedenie elementov semeystva zheleza, oksibarometriya i genesis unikalnykh khromitovykh mestorozhdeniy Kempirsayskogo massiva [Behavior of the iron family elements, oxygen barometry, and genesis of unique chromite deposits of the Kempirsayskiy massif]. Geologiya rudnykh mestorozhdeniy. 51 (2): 140-156. (in Russian)

36. Chashchukhin I.S., Votyakov S.L., Shchapova $Y u . V$. 2007. Kristallokhimiya khromshpineli i oksitermobarometriya ultramafitov skladchatykh oblastey [Crystal chemistry of chrome spinel and oxygen termobarometry of ultramafic rocks of the fold areas]. IGiG UrO RAN, 310 p. (in Russian)

37. Chernyshov A.I. 1996. Identifikatsiya ploskostnykh i lineynykh strukturnykh elementov $\mathrm{v}$ dinamometamorfizovannykh ultramafitakh [Identification of planar and linear structural elements in the dynamometamorphosed ultramafic rocks]. In Dinamometamorfizm i petrostrukturnaya evolyutsiya porod mafitultramafitovoy assotsiatsii. Tomsk, pp. 99101. (in Russian)

38. Chernyshov A.I., Yurichev A.N. 2013. Petrostrukturnaya evolyutsiya ultramafitov Kalninskogo khromitonosnogo massiva v Zapadnom Sayane [Petrostructural evolution of ultramafic rock of the Kalninskiy chromite-bearing massif in the West Sayan]. Geotektonika. 4: 31-46. (in Russian)

39. Shcherbakov S.A. 1990. Pasticheskie defirmatsii ultrabazitov ofiolitovoy assotsiatsii Urala [Plastic deformations of ultrabasic rock of the Urals ophiolite assosiation]. Nauka, Moskva, 120 p. (in Russian) 
40. Yarosh P.Ya. 1980. O pervoistochnike khroma $\mathrm{v}$ dunitakh i prirode aktsessornogo khromita [About the source of chromite in dunites and a nature of accessory chromite]. Zapiski VMO, 109 (1): 98-105. (in Russian)

41. Ballhaus C. 1998. Origin of the podiform chromite deposits by magma mingling. Earth and Planetary Science Letters. 156 (3): 185193. doi: $10.1016 / \mathrm{S} 0012-821 \mathrm{X}(98) 00005-3$

42. Carter N.L. 1976. Steady state flow of rocks. Rev. Geophys. and Space Phys. 14 (3): 301360.

43. Cassard D., Nicolas A., Rabinowitch M., Moutte J., Leblanc M., Prinzhoffer A. 1981. Structural Classification of Chromite Pods in Southern New Caledonia. Econ. Geology. 76: 805-831. doi: 10.2113/gsecongeo.76.4.805

44. Chapman Y. 1969. Dislocations in the deformation of olivine. Amer. J. Sci. 267: 841852.

45. Greenbaum D. 1977. The chromitiferous rocks of the Troodos ophiolite complex, $\mathrm{Cy}$ prus. Econ. Geol. 72 (7): 1175-1194. doi: 10.2113/gsecongeo.72.7.1175

46. Hock M., Friedrich G. 1985. Structural features of ophiolitic chromitites in the Zambales Range, Luzon, Philippines. Mineralium-Deposita. 20: 290-301. doi: 10.1007/BF00204289

47. Karato S.-I., Jung H., Katayama I., Skemer $P h$. 2008. Geodynamic significance of seismic anisotropy of the upper mantle: new insights from laboratory studies. Annu. Rev. Earth Planet. Sci. 36: 59-95. doi: 10.1146/annurev.earth.36.031207.124120
48. Kelemen P. B., Shimizu N., Salters V. J. M. 1995. Extraction of mid-ocean-ridge basalt from the upwelling mantle by focused flow of melt in dunite channels. Nature, 375: 747753. doi: $10.1038 / 375747 \mathrm{a} 0$

49. Lago B.L., Rabinowicz M., Nicolas A. 1982. Podiform chromite ore bodies: a genetic model. J. Petrology. 23 (1): 103-125. Doi: 10.1093/petrology/23.1.103

50. Leblanc M., Ceuleneer G. 1992. Chromite crystallization in a multicellular magma flow: evidence from a chromitite dike in the Oman ophiolite. Litos, 27: 231-257. doi: 10.1016/0024-4937(91)90002-3

51. Matveev S. Ballhaus C. 2002. Role of water in the origin of podiform chromitite deposits. Earth and Planetary Science Letters, 203: 235-243. doi: 10.1016/S0012821X(02)00860-9

52. Nicolas A., Bouchez J.L., Boudier F., Mercier J.C. 1971. Textures, structures and fabrics due to solid state flow in some European lherzolites. Tectonophysics, 12: 55-86. doi: 10.1016/0040-1951(71)90066-7

53. Thayer T. P. 1964. Principal features and origin of podiform chromite deposits, and some observations on the Guleman-Soridag District, Turkey. Econ. Geol., 59: 1497-1524.

54. Zhou M.-F., Robinson P.T., Malpas J., Li Z. 1996. Podiform Chromitites in the Luobusa Ophiolite (SouthernTibet): Implications for Melt-Rock Interaction and Chromite Segregation in the Upper Mantle. J. Petrology, 37 (1): 3-21. doi: 10.1093/petrology/37.1.3. 